\title{
Keratin 19 Epithelial Patterns in Cirrhotic Stroma Parallel Hepatocarcinogenesis
}

\author{
Jochen K.M. Lennerz, ${ }^{* \dagger}$ William C. Chapman, ${ }^{\ddagger}$ \\ and Elizabeth M. Brunt ${ }^{\dagger}$ \\ From the Department of Pathology," Massachusetts General \\ Hospital, Harvard Medical School, Boston, Massachusetts; and \\ the Departments of Pathology and Immunology, ${ }^{\dagger}$ and Surgery, ${ }^{\neq}$ \\ Washington University School of Medicine, St. Louis, Missouri
}

Cirrhotic septa harbor vessels and inflammatory, fibrogenic, and ductular epithelial cells, collectively referred to as the ductular reaction (DR). Lack of the DR in the stromal compartment around hepatocellular carcinoma (HCC) has been documented; however, the relationship of epithelial keratin 19 (K19) structures to progression of intralesional carcinogenesis has not been explored. K19 immunoreactivity in the stromal compartment around 176 nodules in cirrhotic explants was examined. Quantitative differences $(P<0.0001)$ were manifested in three distinct histologically identifiable patterns: "complex" around cirrhotic nodules (CN), "attenuated" around dysplastic nodules (DN), and "absent" around HCC. Markers of necrosis or apoptosis could not explain the perinodular K19 epithelial loss; however, multicolor immunolabeling for K19, vimentin, E-Cadherin, SNAII, and fibroblast-specific protein 1 (FSP-1) demonstrated discrepancies in immunophenotype and cytomorphologic features. Variability of cellular features was accompanied by an overall decrease in epithelial markers and significantly increased fractions of SNAIL- and FSP-1-positive cells in the DR around DN when compared with $C N(P<0.0001)$. Immunolabeling of transforming growth factor- $\beta$ signaling components (TGF $\beta R 1$, SMAD3, and PSMAD2/3) demonstrated increased percentages of pSMAD2/3 around DN when compared with CN $(P<0.0001)$. These findings collectively suggest marked alterations in cellular identity as an underlying mechanism for the reproducible extralesional K19 pattern that parallels progressive stages of intranodular hepatocarcinogenesis. Paracrine signaling is proposed as a link that emphasizes the importance of the epithelial-stromal compartment in malignant progression of HCC in cirrhosis. (Am J Pathol 2011, 179:1015-1029; DOI: 10.1016/j.ajpath.2011.04.040)
In advanced chronic liver disease (cirrhosis) from virtually any cause, cirrhotic nodules (CN) containing hepatocytes are surrounded by perinodular stroma, that is, cirrhotic septa, that consists of an expanded fibrous matrix harboring lymphovascular structures, mixed inflammatory cells, and epithelial cells with ductular phenotype, the "ductular-reaction" (DR ${ }^{1-3}$ (Figure 1A). The presence of these biliary-type epithelial cells between mesenchymal elements makes perinodular cirrhotic septa by definition an epithelial-stromal compartment (ESC) (Figures 1B; see also Supplemental Figure S1 at $h$ ttp://ajp. amjpathol.org). Although this ESC is the primary site for adaptations to sustained injuries (eg, fibrogenesis in chronic inflammation), ${ }^{4,5}$ the number of investigations of the ESC in hepatocarcinogenesis is limited. ${ }^{6-8}$ This is surprising because stromal invasion is a key, if not challenging, ${ }^{6}$ histopathologic feature used to differentiate premalignant dysplastic nodules (DN) from malignant hepatocellular carcinoma (HCC) ${ }^{9-11}$ Furthermore, one of the proposed human stem cell niches resides in the ESC and includes epithelial cells that express type- 1 keratin 19 (K19) (Figure 1A), ${ }^{1,12,13}$ a more specific biliary marker than is type-2 keratin 7., ${ }^{73-15}$

Based on the relatively limited characterization of perinodular ESC surrounding hepatocellular nodules ( $\mathrm{HCN})$ in cirrhosis ${ }^{7,16}$ the present study initially correlated perinodular K19 patterns with the intranodular hepatocellular pathologic alterations and quantified a compelling relationship of intranodular and extranodular findings to demonstrate that the ESC demonstrates significant alterations in the progression from $\mathrm{CN}$ to $\mathrm{DN}$ to HCC that can func-

Accepted for publication April 14, 2011.

Presented in part at the 98th Annual Meeting of the United States and Canadian Academy of Pathology (USCAP), Boston, Massachusetts, March 7-13, 2009; the 99th Annual Meeting of USCAP, Washington, DC, March 20-26, 2010; and the 61st Annual Meeting of the American Association for the Study of Liver Diseases, Boston, Massachusetts, October 29-November 2, 2010.

Supplemental material for this article can be found at http://ajp. amipathol.org or at doi: 10.1016/j.ajpath.2011.04.040

Address reprint requests to Elizabeth M. Brunt, M.D., Department of Pathology and Immunology, Washington University School of Medicine, 660 Euclid Ave., St. Louis, MO. E-mail: EBrunt@path.wustl.edu. 


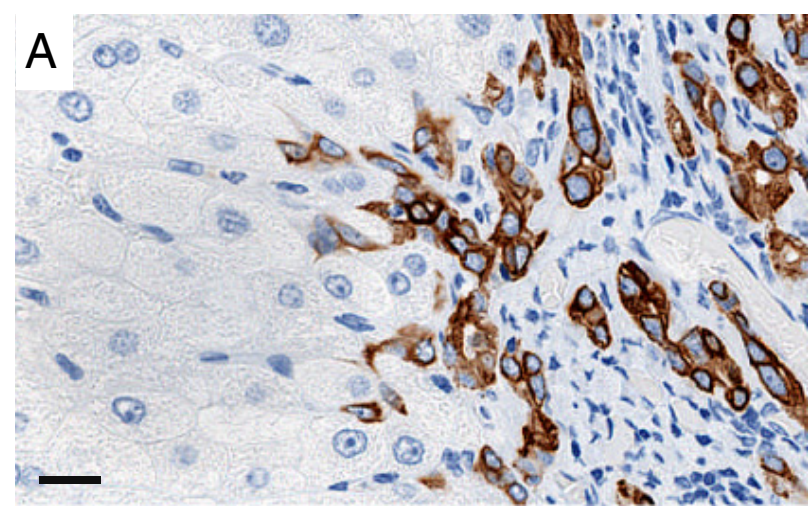

CN: K19

\section{B Cirrhosis}

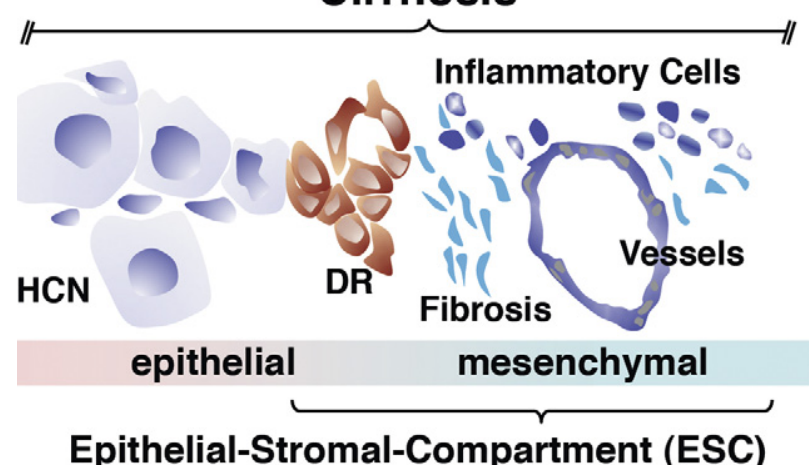

Figure 1. Epithelial-stromal compartment in cirrhosis. A: Hepatocyte inter face demonstrates brisk ductular reaction highlighted by K19 immunostaining within the cirrhotic stroma that also contains vessels and inflammatory and fibrogenic cells (hematoxylin counterstain). The K19-positive cells are interspersed between K19-negative hepatocytes, forming spoke-like extensions oriented perpendicular to the nodular perimeter. Note that some of these juxtahepatocytic K19-positive cells demonstrate weak immunoreactivity. Scale bar $=20 \mu \mathrm{m}$. B: Schematic overview of the relationship of K19positive ductular reaction (DR; red-brown) with adjacent hepatocellular nodules (HCN) and mesenchymal elements (see Supplemental Figure S1 at bttp://ajp.amipathol.org).

tion as a sensitive and specific surrogate for intralesional alterations. The implications of the vanishing epithelial K19 compartment in the progressive stages of hepatocarcinogenesis, however, go beyond routine diagnostics. From studies in other chronic inflammatory conditions of the liver, it is known that K19-positive cells can undergo a phenotype switch referred to as epithelial-to-mesenchymal transition (EMT). ${ }^{4,5}$ Thus, the presence and extent of implicated markers were assessed in the perinodular epithelial compartment surrounding $\mathrm{HCN}$, and findings strongly suggest cellular identity alterations similar to reported phenotype switches as an underlying morphologic mechanism. These new findings suggest paracrine signaling involving the perinodular epithelial-mesenchymal compartment in the multistep process of hepatocarcinogenesis in cirrhosis. Although determination of the direction and exact driving forces will require reliable model systems, results of this comprehensive phenotype assessment demonstrate the extralesional ductular alteration as an indicator, if not a participant, in the peritumoral microenvironment.

\section{Materials and Methods}

\section{Approval and Case Selection}

The Human Studies Committee of Washington University School of Medicine approved the study. Patient samples were chosen as consecutive liver transplant explants from our files and were tested as anonymous samples.

\section{Histologic Analysis}

One of us (E.M.B.) selected nodules from liver explants and applied established diagnostic criteria: CN, DN, and HCC. ${ }^{9-11}$ Differentiation between low- and high-grade dysplasia was not performed. Each $\mathrm{HCN}$ was regarded as a separate lesion, outlined on whole-mount images generated via virtual microscopy (see Supplemental Figure S2, A and B, at http://ajp.amjpathol.org), and another author (J.K.L.), blinded to the diagnosis (H\&E-based), performed an independent review by noting the perinodular K19 pattern for each lesion. Necrosis was defined using established criteria including nuclear swelling, chromatin flocculation (Hoechst 33258 stain), loss of nuclear basophilia (H\&E), and breakdown of cytoplasmic structures including the membrane. ${ }^{17-19}$ Apoptosis was assessed using morphologic features including cell shrinkage, chromatin cleavage, nuclear condensation and formation of pyknotic bodies of condensed chromatin, ${ }^{17,19}$ and abnormal pattern of incorporated Hoechst $33258,{ }^{19-21}$ immunostaining for activated caspase 3, and detection of DNA fragmentation and chromatin cleavage using TUNEL. ${ }^{19,22}$ Cellular phenotype [epithelial (Ep) versus mesenchymal (Me)] was defined via a combination of topographic (Ep, location within confines of basement membrane, versus Me, cellular location within stroma), architectural (Ep, cohesive arrangement in compact configurations, versus $\mathrm{Me}$, individual cells in extracellular matrix), cytomorphologic (Ep, sharp cell borders with polygonal shape, versus Me, elongated ill-defined cytoplasmic outlines), nuclear (Ep, round to oval nucleus with peripheral chromatin condensation and nonprominent nucleolus, versus $\mathrm{Me}$, elongated to spindle-shaped nucleus with isodense chromatin with minimal irregularity and no nucleolus), and immunophenotypic features adapted from proposed criteria. ${ }^{23}$ Cellular identity alteration was defined as discrepancies in these features at the cellular level.

\section{Immunolabeling}

Details of antibodies, dilutions, and staining characteristics are given in Table 1. Immunohistochemistry $(\mathrm{IHC})$ was performed automatically using a Benchmark XT automated slides stainer (Ventana Medical Systems, Inc., Tucson, AZ) using established protocols. ${ }^{24}$ In brief, protocols consisted of pretreatment with $\mathrm{CC} 1$ ( $\mathrm{pH} 8.0)$, incubation with primary antibodies, and detection using an IVIEW-DAB (diaminobenzidine) detection system (catalog No. 760-500; Ventana Medical Systems, Inc.) including ultraview inhibitor, horseradish peroxidase, multimer, chromogen, $\mathrm{H}_{2} \mathrm{O}_{2}$, and copper. For dual-color labeling, 
we used the ultraview Universal Alkaline Phosphatase Red Detection kit (catalog No. 760-501; Ventana Medical Systems, Inc.) including enhancer, naphthol, red A, and fast red B. Immunofluorescence was performed manually according to established protocols. ${ }^{24,25}$ In brief, sections were washed for 5 minutes (xylene $\times 3,100 \%$ ethanol $\times 2$, $95 \%$ ethanol $\times 1,70 \%$ ethanol $\times 1$, and PBS $\times 1$ ), boiled in Trilogy for antigen retrieval (Cell Marque, Hot Springs, $A R$ ), rinsed in deionized water for 15 minutes, and washed with PBS. Sections were blocked in $1 \%$ bovine serum albumin and $0.3 \%$ Triton X-100 in PBS and were incubated using combinations of the primary antibodies. Visualization used secondary antibodies conjugated to Alexa Fluor 488 (green), 596 (red), and 647 (magenta) (Molecular Probes, Eugene, OR) at 1:500. Nuclear counterstaining was optimized to differentiate epithelial from mesenchymal nuclei using titrated Hoechst 33258 stain (blue) at 1:20,000 for 5 minutes (dark) or hematoxylin counterstaining for 4 seconds, both at room temperature.

\section{Controls}

Staining properties and specificity have been determined previously (Table 1), which we additionally ascertained using i) preabsorption controls using the peptides against which the antibodies were raised at 1:10 and 1:20 dilution; ii) normal serum control in which the primary antibody was replaced with normal (rabbit) serum using 1:10 and 1:20 concentrations; iii) negative control (secondary antibody used without the primary antibody, which was replaced with Tris-buffered saline solution); and iv) comparison control on normal tissues ( \pm ) and comparison with expression data from publicly available sources (http://www.proteinatlas.org; last accessed March 19, 2011). ${ }^{26}$

\section{TUNEL Staining}

TUNEL staining was performed using the ApopTag Peroxidase In Situ Apoptosis Detection Kit (Millipore Corp., Billerica, MA). In brief, deparaffinized tissue sections 5 $\mu \mathrm{m}$ thick were washed in PBS and incubated for 30 minutes at $37^{\circ} \mathrm{C}$ with $10 \mu \mathrm{g} / \mathrm{mL}$ proteinase $\mathrm{K}$ (S3020; Dako Corp., Carpinteria, CA). After quenching of endogenous peroxidase with $3 \% \mathrm{H}_{2} \mathrm{O}_{2}$ in PBS for 5 minutes, washes, and 15-minute transfer into equilibration buffer, sections were incubated with TDT (terminal deoxynucleotidyl transferase) enzyme at $10 \mathrm{U} / 50 \mathrm{pL}$, and digoxigeninlabeled nucleotides in a preheated humidified chamber at $37^{\circ} \mathrm{C}$ for 60 minutes. Subsequent incubation with antidigoxigenin-peroxidase for 30 minutes and color development with $\mathrm{H}_{2} \mathrm{O}_{2}$-diaminobenzidine for 5 to 6 minutes was followed by counterstaining using methyl green (S1962; Dako Corp.). Evaluation included positive (intestinal mucosa) and negative (omission of TDT) controls according to established protocols. ${ }^{22}$

\section{Microscopy}

For light microscopy, either slides were scanned using a ScanScope XT scanner (Aperio Technologies, Inc., Vista, CA) or images were captured using a 12 Mpixel Olympus DP70 camera attached to an Olympus BX51 light microscope (Olympus America, Center Valley, PA). An Axiovert 200 with a 1.4 Mpixel Axiocam MRM camera and Apotome optical sectioning filter was used for acquisition of immunofluorescence images (Carl Zeiss Imp Corp., Maple Grove, MN).

Quantification was performed in perinodular sectors defined using the following histologic landmarks: $<25 \%$ of the perinodular circumference starting at a random point, determined using a random-number generator [RandBetween (1-361)]; and the interface between the hepatocellular nodule and the surrounding perinodular stroma formed the internal border of the perinodular sector; whereas the external border was defined by outward projection of the internal border to half of the septal thickness (see Supplemental Figure S2, C and D at http://ajp. amjpathol.org). K19 quantification (cell and profile counts) was determined covering the entire sector using wholeslide imaging. For high-power quantification, we determined the number of high-power fields necessary to capture at least 1000 biliary epithelial cells $(n=27$ fields around $\mathrm{CN}$ ); accordingly, at least 27 fields per marker were quantified. Cells were defined via marker co-localized with nuclear staining in the same plane, whereas the outline of at least one cell formed a profile. Computer-assisted quantification algorithms were applied, ${ }^{24}$ and segmentation of cells and profiles was achieved using threshold filters in combination with circularity and size cutoffs using "cell counter" and "analyze particle" plug-ins in ImageJ software (National Institutes of Health, Bethesda, MD). A customized link ${ }^{24}$ between ImageJ, Photoshop CS3 (Adobe Systems, Inc., San Jose, CA), and ImageScope (Aperio Technologies, Inc.) was generated using AutolT (version 3.2.12.0 by Jonathan Bennett), a freeware scripting language for automating the graphic user interface.

\section{Density Modeling}

To test whether the density of K19 elements can be explained by dispersion over a larger area alone, we compared observed densities around DN and HCC using modeled densities calculated using the observed cell number around $\mathrm{CN}$ in combination with the mean areas of sectors around DN and HCC.

\section{Statistical Analysis}

Unpaired Student's t-tests, $\kappa$ statistic, and intraclass coefficient were used, with $P<0.05$ considered significant. Sample size estimation followed suggestions by Silcocks, ${ }^{27}$ and assuming a $\kappa_{\min }$ of 0.75 and $P<0.05$ for three diagnostic categories, we determined the minimal samples size of 86 , which was doubled for this study. Data were analyzed using Prism 5.0b (GraphPad Software, Inc., San Diego, CA), Microsoft Excel 2008 (version 12.1.9; Microsoft Corp., Redmond WA), or the online statistical toolbox of the Chinese University of Hong Kong 
1018 Lennerz et al

AJP August 2011, Vol. 179, No. 2

Table 1. List of Antibodies

\begin{tabular}{|c|c|c|c|c|c|c|}
\hline Name & Host & Antigen characteristics & $\begin{array}{l}\text { Source catalog } \\
\text { or order no. }\end{array}$ & Dilution & Pattern & Reference \\
\hline $\begin{array}{l}\text { Activated } \\
\text { caspase } 3\end{array}$ & Rabbit (p) & $\begin{array}{l}\text { Synthetic peptide } \\
\text { corresponding to } \\
\text { Ser29+ of human } \\
\text { caspase } 3 \text { ( } N \text { terminus } \\
\text { of p17 subunit) }\end{array}$ & $\begin{array}{l}\text { Abcam, Inc. } \\
\text { ab-32042 }\end{array}$ & $1: 50$ & $\mathrm{C}$ & $\begin{array}{l}28 \\
29\end{array}$ \\
\hline $\begin{array}{l}\text { E-cadherin } \\
\quad(\mathrm{ECAD} / \mathrm{CDH} 1)\end{array}$ & Mouse (m) & $\begin{array}{l}\text { Human transmembrane } \\
\text { protein } 36\end{array}$ & $\begin{array}{l}\text { Ventana } \\
\text { Medical } \\
\text { Systems, } \\
\text { Inc. } \\
790-4497\end{array}$ & $\begin{array}{l}\text { Prediluted by } \\
\text { manufacturer }\end{array}$ & $M / C$ & 85 \\
\hline $\begin{array}{l}\mathrm{K} 7 \\
(\mathrm{CK} 7 / \mathrm{K} 2 \mathrm{C} 7)\end{array}$ & Mouse (m) & Clone OV-TL 12/30 & $\begin{array}{l}\text { Cell Marque, } \\
\text { Corp. } \\
\text { CMA538 }\end{array}$ & $\begin{array}{l}\text { Prediluted by } \\
\text { manufacturer }\end{array}$ & $\mathrm{C}$ & 13 \\
\hline $\begin{array}{l}\text { K19 } \\
\text { (CK19/K1CS) }\end{array}$ & Mouse (m) & $\begin{array}{l}\text { Clone RCK108 } \\
\text { (Immunogen: Human } \\
\text { Cell line T24) }\end{array}$ & $\begin{array}{l}\text { Dako Corp. } \\
\text { M0888 }\end{array}$ & $1: 100$ & $\mathrm{C}^{*}$ & $\begin{array}{l}13 \\
84\end{array}$ \\
\hline $\begin{array}{l}\text { K19 } \\
\text { (CK19/K1CS) }\end{array}$ & Mouse (m) & Clone A53-B/A2.26 & $\begin{array}{l}\text { Ventana } \\
\text { Medical } \\
\text { Systems, } \\
\text { Inc. } \\
760-4281\end{array}$ & $\begin{array}{l}\text { Prediluted by } \\
\text { manufacturer }\end{array}$ & $\mathrm{C}^{*}$ & $\begin{array}{l}13 \\
84\end{array}$ \\
\hline $\begin{array}{l}\text { pSMAD3 } \\
\text { (Figure 5, } \\
\text { A and B) }\end{array}$ & Rabbit (p) & $\begin{array}{l}\text { Synthetic phosphopeptide } \\
\text { corresponding to } \\
\text { residues surrounding } \\
\text { Ser } 423 / 425 \text { of SMAD3 }\end{array}$ & $\begin{array}{l}\text { Cell Signaling } \\
\text { Technology, } \\
\text { Inc. } \\
9520 \text { S }\end{array}$ & $1: 100$ & $\mathrm{~N}$ & $\begin{array}{l}85 \\
87\end{array}$ \\
\hline $\begin{array}{l}\text { pSMAD2/3 } \\
\text { (Figure 5, C-H) }\end{array}$ & Goat $(p)$ & $\begin{array}{l}\text { Short amino acid } \\
\text { sequence containing } \\
\text { phosphorylated Ser423/ } \\
425 \text { of human SMAD3 }\end{array}$ & $\begin{array}{l}\text { Santa Cruz } \\
\text { Biotechnology, } \\
\text { Inc. } \\
\text { sc11769 } \\
\text { (peptide } \\
\text { sc-11769P) }\end{array}$ & $1: 50$ & $\mathrm{~N}$ & 4 \\
\hline $\begin{array}{l}\text { S100 } \\
\quad \text { (Figure S4B) }\end{array}$ & Rabbit (p) & $\begin{array}{l}\text { Purified, full-length, native } \\
\text { bovine } \mathrm{S} 100 \text { protein }\end{array}$ & $\begin{array}{l}\text { Ventana } \\
\text { Medical } \\
\text { Systems, Inc. } \\
760-2523\end{array}$ & $\begin{array}{l}\text { Prediluted by } \\
\text { manufacturer }\end{array}$ & $\mathrm{C}$ & 88 \\
\hline $\begin{array}{l}\text { SMAD3 } \\
\quad \text { (Figure 5, } \\
\quad \text { D, E, G, H) }\end{array}$ & Rabbit (p) & $\begin{array}{l}\text { Synthetic peptide } \\
\text { corresponding to } \\
\text { AA100-150 of human } \\
\text { SMAD3 }\end{array}$ & $\begin{array}{l}\text { Thermo Fisher } \\
\text { Scientific, } \\
\text { Inc. } \\
\text { PA1-38613 }\end{array}$ & $1: 100$ & $C^{*}$ & 89 \\
\hline $\begin{array}{l}\text { SMAD3 } \\
\text { (Figure S6A) }\end{array}$ & Rabbit (p) & $\begin{array}{l}\text { Synthetic peptide } \\
\text { corresponding to } \\
\text { residues at the AA } \\
\text { terminus of human } \\
\text { SMAD3 }\end{array}$ & $\begin{array}{l}\text { Cell Signaling } \\
\text { Technology, } \\
\text { Inc. } \\
9523 S\end{array}$ & $1: 100$ & $C^{*}$ & 90 \\
\hline $\begin{array}{l}\text { SMAD4 } \\
\text { (Figure S6B) }\end{array}$ & Rabbit (p) & $\begin{array}{l}\text { Recombinant protein } \\
\text { epitope signature tag } \\
\text { (PrEST) corresponding } \\
\text { to AA118-240 of human } \\
\text { SMAD4 }\end{array}$ & $\begin{array}{l}\text { Sigma-Aldrich } \\
\text { Corp. } \\
\text { HPA019154 }\end{array}$ & $1: 150$ & $\mathrm{C}^{*}$ & $\begin{array}{l}91 \\
92\end{array}$ \\
\hline SMAD4 & Rabbit (p) & $\begin{array}{l}\text { Synthetic peptide } \\
\text { corresponding to } \\
\text { residues surrounding } \\
\text { Pro278 of human } \\
\text { SMAD4 }\end{array}$ & $\begin{array}{l}\text { Cell Signaling } \\
\text { Technology, } \\
\text { Inc. } \\
9515\end{array}$ & $1: 100$ & $\mathrm{C}^{*}$ & $\begin{array}{l}93 \\
94\end{array}$ \\
\hline $\begin{array}{l}\text { pSMAD2 } \\
\text { (Figure S6C) }\end{array}$ & Rabbit (p) & $\begin{array}{l}\text { Synthetic phosphopeptide } \\
\text { corresponding to } \\
\text { residues surrounding } \\
\text { Ser } 465 / 467 \text { of human } \\
\text { SMAD2 }\end{array}$ & $\begin{array}{l}\text { Cell Signaling } \\
\text { Technology, } \\
\text { Inc. } \\
3101 S\end{array}$ & $1: 100$ & $\mathrm{~N}$ & 95 \\
\hline $\begin{array}{l}\text { pSMAD2 } \\
\text { (Figure S6D) }\end{array}$ & Rabbit (p) & $\begin{array}{l}\text { Synthetic phosphopeptide } \\
\text { corresponding to } \\
\text { residues surrounding } \\
\text { Ser } 245 / 250 / 255 \text { of } \\
\text { human SMAD2 }\end{array}$ & $\begin{array}{l}\text { Cell Signaling } \\
\text { Technology, } \\
\text { Inc. } \\
3104 S\end{array}$ & $1: 100$ & $\mathrm{~N}$ & 96 \\
\hline $\begin{array}{l}\text { SNAIL } \\
\text { (SNAI1/SLUGH2) }\end{array}$ & Rabbit (p) & $\begin{array}{l}\text { Synthetic KLH-conjugated } \\
\text { peptide AA1-100 of } \\
\text { human Snail }\end{array}$ & $\begin{array}{l}\text { Abcam, Inc. } \\
\text { ab-17732 } \\
\text { (peptide } \\
\text { ab19126) }\end{array}$ & $\begin{array}{l}1: 100 \\
150(\mathrm{IF})\end{array}$ & $\mathrm{N}$ & e continues) \\
\hline
\end{tabular}


Table 1. Continued

\begin{tabular}{|c|c|c|c|c|c|c|}
\hline Name & Host & Antigen characteristics & $\begin{array}{l}\text { Source catalog } \\
\text { or order no. }\end{array}$ & Dilution & Pattern & Reference \\
\hline $\begin{array}{l}\text { TGF } \beta 1 R \\
\quad(A L K-5)\end{array}$ & Rabbit $(p)$ & $\begin{array}{l}\text { Synthetic peptide } \\
\text { corresponding to } \\
\text { AA158-179 of human } \\
\text { TGFb1R }\end{array}$ & $\begin{array}{l}\text { Abcam, Inc. } \\
\text { ab-31013 }\end{array}$ & $1: 50$ & $M / C$ & 98 \\
\hline $\begin{array}{l}\text { FSP-1 } \\
\quad(S 100-A 4)\end{array}$ & Rabbit (p) & $\begin{array}{l}\text { Recombinant protein } \\
\text { encoding full-length } \\
\text { human FSP-1/S100-A4 }\end{array}$ & $\begin{array}{l}\text { Abcam, Inc. } \\
\text { ab-27427 }\end{array}$ & $\begin{array}{l}\text { Prediluted by } \\
\text { manufacturer }\end{array}$ & $\mathrm{C} / \mathrm{N}$ & $\begin{array}{r}4 \\
43 \\
44\end{array}$ \\
\hline Vimentin & $\begin{array}{l}\text { Mouse } \\
\qquad(\mathrm{m})\end{array}$ & Clone V9 & $\begin{array}{l}\text { Ventana } \\
\text { Medical } \\
\text { Systems, } \\
\text { Inc. } \\
790-2917\end{array}$ & $\begin{array}{l}\text { Prediluted by } \\
\text { manufacturer }\end{array}$ & C & 99 \\
\hline
\end{tabular}

${ }^{*}$ Staining pattern identical.

C, cytoplasmic staining; IF, immunofluorescence; K19, cytokeratin 19; m, monoclonal; M, membranous staining pattern; N, nuclear; p, polyclonal.

Antibody source locations were as follows: Abcam, Inc., Cambridge, MA; Ventana Medical Systems, Inc., Tucson, AZ; Cell Marque, Corp., Hot Springs, AR CA; Dako Corp., Carpinteria, CA; Cell Signaling Technology, Inc., Beverly, MA; Santa Cruz Biotechnology, Inc., Santa Cruz, CA; Thermo Fisher Scientific, Inc., Rockford, IL; Sigma-Aldrich Corp., St. Louis, MO; Abcam, Inc., Cambridge, MA.

by Prof. Allan Chang (http://department.obg.cuhk.edu.hk researchsupport/statmenu.asp; last accessed March 19, 2011). Statistical performance measures and confidence intervals were determined using the Hutchon toolkit ( $h$ ttp:// www.hutchon.net/EPRval.htm; last accessed March 19, 2011).

\section{Results}

The study cohort consisted of $176 \mathrm{HCN}$ [mean: $n=5$ per liver (range $n=3-7$ )] from 32 cirrhotic liver explants.
Each $\mathrm{HCN}$ was assigned to one appropriate diagnosis (CN, DN, or HCC) according to established criteria. $^{10,11,25}$ Based on these diagnoses, the cohort consisted of 170 nodules: $71 \mathrm{CN}, 45 \mathrm{DN}$, and $54 \mathrm{HCC}$ (Figure 2, $A$ and $B$ ). Five HCN demonstrated a nodule-in-nodule configuration, ${ }^{9-11}$ and one $\mathrm{CN}$ exhibited mixed features of DN; these six HCN were assigned to the DN category (subgroup with atypical or overlapping features). The representative nature of the cohort was ascertained by inclusion of a variety of underlying liver diseases and morphometric confirmation of size differences between
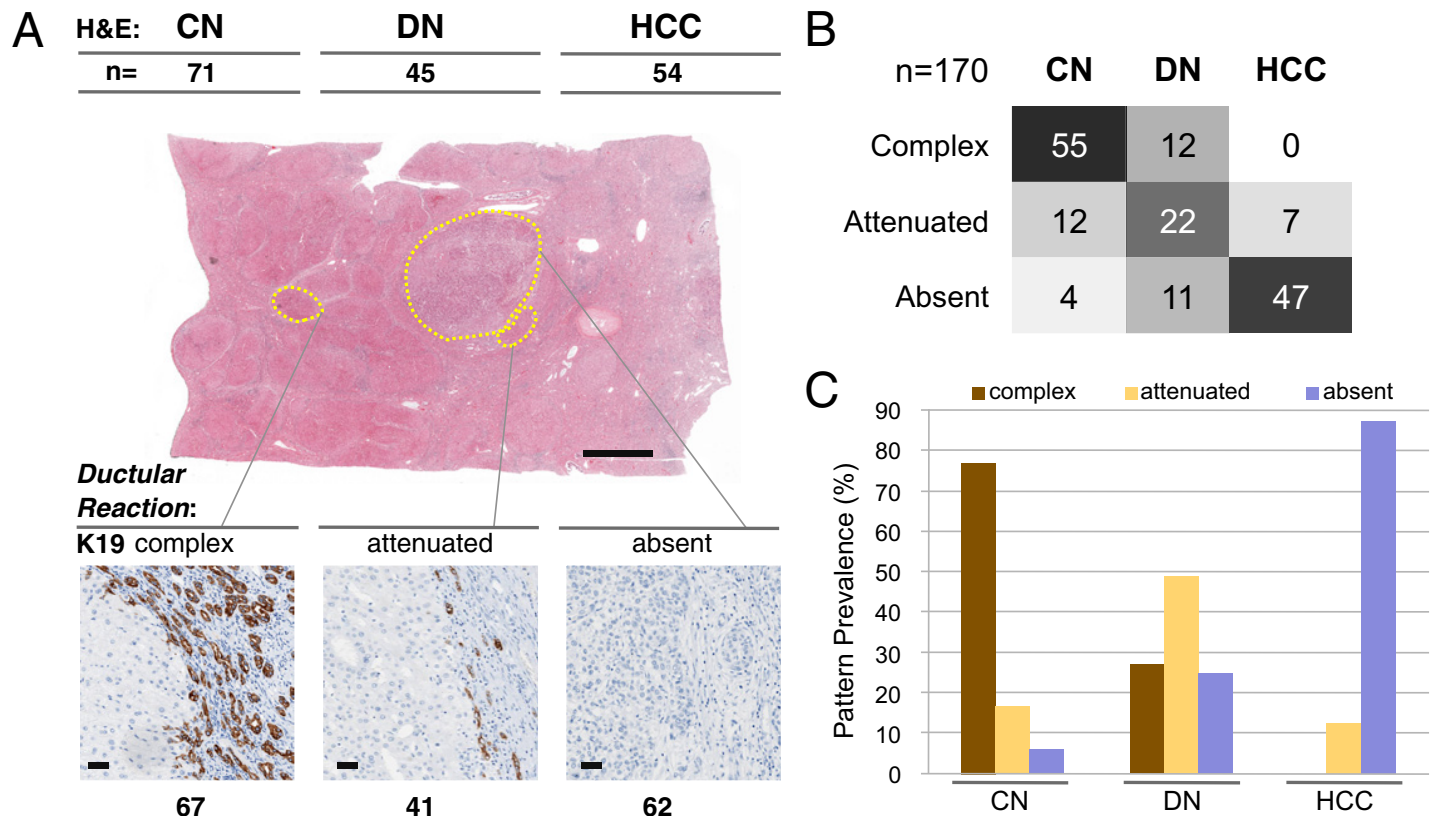

Figure 2. Perinodular K19 pattern. A: Number of hepatocellular nodules diagnosed using H\&E staining as cirrhotic nodules (CN), dysplastic nodules (DN), or hepatocellular carcinoma (HCC) is provided. Representative nodules are outlined on an H\&E-stained histotopogram. The total number of nodules assigned to the appropriate pattern of perinodular ductular reaction is provided along with a representative image. See Results for detailed descriptions of the three patterns: complex, attenuated, and absent. Scale bars: whole mount, $5 \mathrm{~mm}$; insets, $50 \mu \mathrm{m}$. B: Correlation matrix of H\&E-based diagnostic categories (columns, diagnosis by H\&E) with perinodular K19 pattern (rows). Each field of the matrix shows the absolute number of lesions per combination of category and pattern, and the background gray scale encodes the relative frequency. Thereby, correlation is visualized as a darker diagonal from the top left to the bottom right (see Results). C:. Bar graph demonstrates prevalence of K19 pattern in each diagnostic category: CN, DN, and HCC. The highest prevalence of the complex pattern was observed around $\mathrm{CN}$, the attenuated pattern around DN, and the absent pattern around HCC. The complex perinodular K19 pattern was not observed around HCC. Statistical performance measures are given in Table 2. 
Table 2. Statistical Performance Measures of Perinodular K19 Pattern

\begin{tabular}{lcc}
\hline & \multicolumn{2}{c}{ Hepatocellular Nodules } \\
\cline { 2 - 3 } \multicolumn{1}{c}{ Variable } & $\begin{array}{c}\text { Without atypical features } \\
(n=170)\end{array}$ & $\begin{array}{c}\text { With atypical features } \\
(n=176)\end{array}$ \\
\hline True positive & 47 & 47 \\
False positive & 15 & 20 \\
True negative & 101 & 102 \\
False negative & 7 & 7 \\
Sensitivity (95\% CI) & $87.04(75.1-94.6)$ & $87.04(75.1-94.6)$ \\
Specificity (95\% Cl) & $87.07(79.6-92.6)$ & $83.61(75.8-89.7)$ \\
Positive predictive value $(95 \% \mathrm{Cl})$ & $75.80(63.3-85.8)$ & $70.15(57.7-80.7)$ \\
Negative predictive value & $93.5(87.1-97.4)$ & $93.6(87.2-97.4)$ \\
Accuracy & 87.06 & 84.7 \\
Likelihood ratio & 6.731 & 5.309 \\
Pretest odds positive & 0.47 & 0.44 \\
Posttest odds positive & 3.13 & 2.35
\end{tabular}

Validity comparison of HCN without $(N=170)$ and with $(N=170+6)$ atypical features for $\mathrm{K} 19$ versus H\&E and HCC (positive) versus non-HCC (negative)

$\mathrm{Cl}$, confidence interval (calculated with binomial expansion); HCC, hepatocellular carcinoma; K19, cytokeratin 19.

CN, DN, and HCC (see Supplemental Tables S1 and S2 at $h$ ttp://ajp.amjpathol.org).

\section{Perinodular Structure of K19 Patterns Are Complex, Attenuated, and Absent}

Three patterns of DR surrounding CN, DN, and HCC, ie, complex, attenuated, and absent, respectively, were reproducibly documented. An overview is shown in Figure 2A. Specifically, the DR around CN demonstrated numerous ductules consisting of interlacing epithelial clusters that blended into the hepatocyte interface. Three arbitrary zones could be distinguished (see Supplemental Figure S2D at http://ajp.amjpathol. org): i) central regions of the internodular septa contained larger ductules, referred to as internodular ducts, often interspersed with thin-walled vessels; ii) the perinodular zone, in which a mixture of ring-shaped ductules and small circular epithelial groups, with or without a central lumen, predominates; and iii) an interface in which slender strings of biliary-type epithelial cells are located between hepatocytes and merge into $\mathrm{HCN}$, resulting in a radial or spoke-like appearance with orientation of cells perpendicular to the perimeter of the nodule. These features are readily appreciated using K19 labeling, and the pattern of DR was termed "complex" (Figures 1A and 2A). The DR around DN demonstrated a well-demarcated interface zone characterized by absence of interspersed biliary-type elements (loss of radial spokes) (Figure 2A), and the remaining epithelial elements were fragmented and predominated as small accumulations of slender cells oriented parallel to the perimeter of the HCN (Figure 2A). Depletion of ductules with lumina left the remaining cellular aggregates as thin cores of ovoid to elongated cells rather than tubular formations ("attenuation"). Internodular ductules around DN were preserved but typically located closer to the surrounding CN. The stroma around well-differentiated HCC was depleted of biliary-type epithelial elements, and the DR and K19 immunoreactivity was "absent" (Figure 2A).

\section{Perinodular K19 Pattern as a Valid Surrogate for Intranodular Disease}

Investigations were performed to determine whether perinodular patterns correlated with HCN (Figure 2). To ensure an unbiased review, nodules were outlined on whole-mount maps, and one K19 pattern was assigned to each nodule. The K19 patterns in the diagnostic groups CN, DN, and HCC included 67 complex, 41 attenuated, and 62 absent, respectively, resulting in substantial correlation with H\&E-based diagnoses (Figure 2B). The intraclass coefficient for H\&E versus $\mathrm{K} 19$ was $0.878(P<0.02)$, and differentiation of nonHCC (CN plus DN) versus HCC was almost perfect (0.899; $P<0.0001)$. The negative predictive value of the complex pattern for HCC was $94 \%$. Some DN demonstrated the K19 pattern typically observed around CN (12 of $45 ; 26 \%$ ) and individual DN demonstrating absence of perinodular K19 (11 of 45; 24\%) (Figure 2, B and C); this overlap was compatible with separate diagnostic groups applied on a continuous biological spectrum. The six additional DN with atypical or overlapping features using H\&E-based diagnosis demonstrated absence of DR in the five HCN with a nodulein-nodule configuration and a complex pattern in the $\mathrm{CN}$ with mixed features. Comparison of statistical performance measures with and without these six additional nodules using a binary classification of HCC versus non-HCC (CN plus DN) is given in Table 2 and confirmed that the perinodular K19 pattern can function as an accurate surrogate for intranodular disease.

\section{Quantification of Perinodular K19 Pattern}

Next, a more objective quantitative approach was undertaken, and extraction of 56,378, 9008, and 63 cells and 
Table 3. Quantification of Perinodular K19 Compartment

\begin{tabular}{|c|c|c|c|c|c|c|c|c|c|}
\hline Variable & \multicolumn{3}{|c|}{$\mathrm{CN}(N=71)$} & \multicolumn{3}{|c|}{$\mathrm{DN}(N=45)$} & \multicolumn{3}{|c|}{$\operatorname{HCC}(N=54)$} \\
\hline DR H\&E & \multicolumn{3}{|c|}{+++} & \multicolumn{3}{|c|}{+} & \multicolumn{3}{|c|}{-} \\
\hline Pattern & \multicolumn{3}{|c|}{ Complex } & \multicolumn{3}{|c|}{ Attenuated } & \multicolumn{3}{|c|}{ Absent } \\
\hline K19 & $\mathrm{n}^{+}$ & $P_{\mathrm{CD}}$ & $\%$ & $\mathrm{n}^{+}$ & $P_{\mathrm{DH}}$ & $\% \mathrm{CN}$ & $\mathrm{n}^{+}$ & $P_{\mathrm{CH}}$ & $\% \mathrm{CN}$ \\
\hline $\begin{array}{l}\text { Profiles } \\
\text { (sectors) }\end{array}$ & $408.9 \pm 23(36)$ & $1.5 e^{-14}$ & $\overline{\text { Set } 100}$ & $106.3 \pm 14(27)$ & $4.1 e^{-10}$ & 26 & $1.52 \pm 0.2(30)$ & $1.7 e^{-23}$ & 0.4 \\
\hline $\begin{array}{l}\text { Cells } \\
\text { (sectors) }\end{array}$ & $2088 \pm 262(27)$ & $2.9 e^{-9}$ & Set 100 & $300 \pm 44(30)$ & $1.3 e^{-5}$ & 14 & $2.4 \pm 0.3(27)$ & $1.4 e^{-7}$ & 0.1 \\
\hline $\begin{array}{l}\text { Density, cells/ } \\
\mathrm{mm}^{2} \text { (sectors) }\end{array}$ & $16925 \pm 2191(27)$ & $1.6 e^{-9}$ & Set 100 & $1610 \pm 429(30)$ & $5.8 e^{-4}$ & 5.8 & $9.6 \pm 3.3(27)$ & $6.8 e^{-10}$ & 0.02 \\
\hline Marker (HPF) & $\Sigma^{+} / \Sigma_{t}$ & $x^{+} / x_{t}$ & $\%_{t}$ & $\Sigma^{+} / \Sigma$ & $x^{+} / x_{t}$ & $\%_{t}$ & $\%$ & & \\
\hline $\begin{array}{r}\text { FSP-1 } \\
(27)\end{array}$ & $\frac{140}{1344}$ & $\frac{5.19 \pm 0.4}{49.8 \pm 4.3}$ & $10^{*}$ & $\frac{106}{175}$ & $\frac{3.9 \pm 0.3}{6 \pm 0.6}$ & $65^{\star}$ & $\mathrm{N}$ & & \\
\hline $\begin{array}{c}\text { ECADH } \\
(54)\end{array}$ & $\frac{2777}{3412}$ & $\frac{51.4 \pm 4}{63.2 \pm 5}$ & 80 & $\frac{377}{487}$ & $\frac{7 \pm 0.6}{9 \pm 0.7}$ & 77 & $\mathrm{~N}$ & & \\
\hline $\begin{array}{l}\text { SNAIL } \\
(27)\end{array}$ & $\frac{696}{2068}$ & $\frac{25.8 \pm 2.3}{76.6 \pm 7.7}$ & $34^{*}$ & $\frac{161}{312}$ & $\frac{5.96 \pm 0.6}{11.6 \pm 1.2}$ & $52^{*}$ & $\mathrm{~N}$ & & \\
\hline $\begin{array}{l}\text { TGFBR1 } \\
\text { (27) }\end{array}$ & $\frac{1095}{2293}$ & $\frac{40.6 \pm 3.6}{84.9 \pm 7.6}$ & $48^{*}$ & $\frac{39}{248}$ & $\frac{1.4 \pm 0.2}{9.2 \pm 0.8}$ & $15^{*}$ & $\mathrm{~N}$ & & \\
\hline $\begin{array}{l}\text { SMAD3 } \\
\text { (27) }\end{array}$ & $\frac{1573}{2293}$ & $\frac{58.3 \pm 5}{84.9 \pm 7.6}$ & 68 & $\frac{184}{248}$ & $\frac{6.8 \pm 0.5}{9.2 \pm 0.8}$ & 74 & $\mathrm{~N}$ & & \\
\hline $\begin{array}{l}\text { pSMAD2/3 } \\
\text { (27) }\end{array}$ & $\frac{619}{2293}$ & $\frac{22.9 \pm 2}{84.9 \pm 7.6}$ & $27^{*}$ & $\frac{148}{248}$ & $\frac{5.5 \pm 0.5}{9.2 \pm 0.8}$ & $60^{*}$ & $\mathrm{~N}$ & & \\
\hline
\end{tabular}

Values $\left(\mathrm{n}^{+}\right)$are given as mean \pm SEM over the number of examined sectors. $P$ values were determined using the Student $t$-test $\left(P_{\mathrm{CD}}\right.$, CN versus DN; $P_{\mathrm{DH}}$, DN versus $\mathrm{HCC} ; P_{\mathrm{CH}}$, CN versus $\mathrm{HCC}$ ).

${ }^{*} P<0.0001$ (Fisher's exact test, marker fraction $C N$ versus marker fraction DN).

+ , present; +++, numerous; -, absent; \%, percentage of marker-positive elements normalized to the total number of perinodular epithelial cells; \% $\mathrm{CN}$, percentage of immunoreactive elements normalized to the number observed in the epithelial-stromal compartment surrounding CN; CN, cirrhotic nodule; DN, dysplastic nodule; DR, ductular reaction; HCC, hepatocellular carcinoma; $N$ = number of hepatocellular nodules (CN, DN, or HCC); HPF, high-power fields within sectors; K19, cytokeratin 19 immunohistochemistry; $n^{+}$, number of immunoreactive elements (profiles or cells); NA, not applicable $\mathrm{x}^{+} / \mathrm{x}_{\mathrm{t}}$, average cell number per high-power field \pm SEM over average total number of cells in perinodular epithelial compartment; $\Sigma^{+} / \Sigma_{\mathrm{t}}$, sum of all marker-positive cells over sum of all cells in perinodular epithelial compartment.

$14,722,2869$, and 45 profiles in perinodular sectors of $\mathrm{CN}, \mathrm{DN}$, and HCC, respectively, was performed. Density of cells and profiles was expressed per sector $\mu \mathrm{m}^{2}$, and statistical comparison demonstrated a highly significant reduction in K19-positive elements from CN to DN to HCC (Table 3). Of note, when cellular density around the larger $\mathrm{DN}$ and $\mathrm{HCC}$ was calculated (using numbers observed in $\mathrm{CN}$ sectors), the modeled sector densities around DN $\left(5353 \pm 671 / \mathrm{mm}^{2}\right)$ and HCC $\left(2784 \pm 349 / \mathrm{mm}^{2}\right)$ significantly exceeded the observed number (Table $3 ; P_{D N}<$ 0.0001 and $P_{H C C}<0.0001$, unpaired Student's $t$-test). These mathematical considerations excluded $\mathrm{K} 19$ reduction around the DN and HCC based on dispersion over a larger area alone (DN observed $74 \%$ versus modeled $57 \%$; HCC observed $99.6 \%$ versus modeled $78 \%$; all normalized to $\mathrm{CN}$ ). On the cellular level, the differences were even more pronounced, and an $86 \%$ reduction around DN was observed, whereas the reduction was 99.9\% around HCC (Table 3). Based on the reductions in cell versus profile counts, the mean number of cells per profile was determined [CN, $5.13 \pm 0.5$ (range, 1 to 13 ); DN, $2.88 \pm 0.15$ (range, 1 to 4 ); and HCC, $1.69 \pm 0.2$ (range, 0.1 to 3)], and comparison demonstrated highly significant differences $\left(P_{\mathrm{CN}}\right.$ versus $P_{\mathrm{DN}}=1.23 \mathrm{e}^{-4} ; P_{\mathrm{CN}}$ versus $P_{\mathrm{HCC}}=1.43 \mathrm{e}^{-7}$; and $P_{\mathrm{DN}}$ versus $P_{\mathrm{HCC}}=$ $\left.1.34 \mathrm{e}^{-5}\right)$. These values confirmed that fewer cells contribute to perinodular profile counts in the progressive stages of hepatocarcinogenesis and support the morphologic rather than temporal descriptors complex, attenuated, and absent.

\section{Necrosis and Apoptosis Are Not the Principal Morphologic Mechanisms for Perinodular K19 Loss}

Because both apoptosis and necrosis are mechanisms of cell loss and are associated with distinct morphologic and nuclear hallmarks, H\&E- and Hoechststained sections were evaluated. Neither cytologic nor nuclear features of epithelial necrosis were observed (Figure 3,A and F). Likewise, DR around HCN did not demonstrate cytomorphologic evidence of apoptosis (Figure 3B). However, in contrast to necrosis, during apoptosis the cell membrane and nuclear features remain intact for a relatively long time, and identification of early apoptosis may not be reliable. ${ }^{19}$ Therefore, 


\section{Loss of perinodular K19}

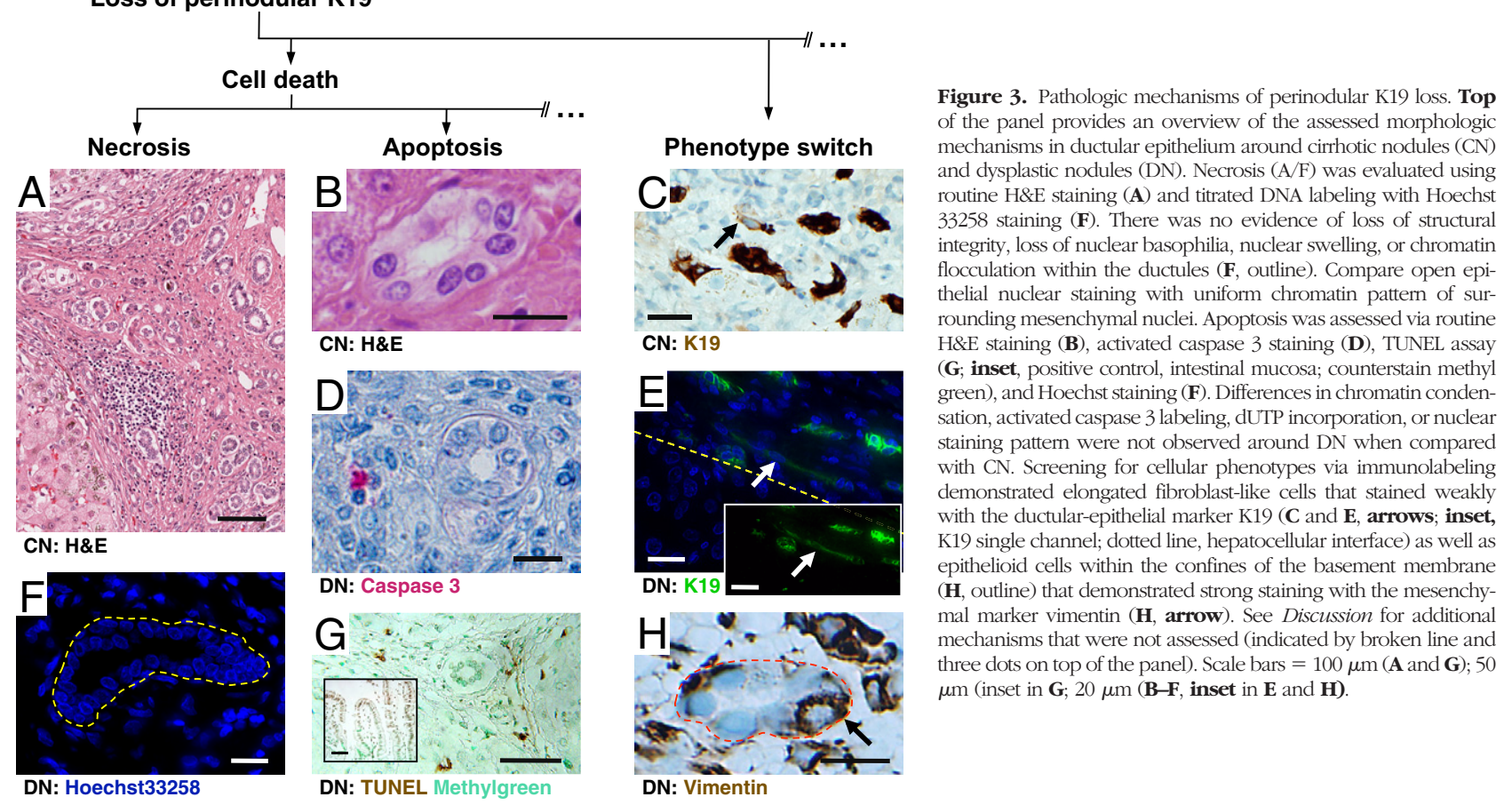

activated caspase 3 was evaluated using immunolabeling $^{28,29}$ (Figure 3D). No differences in percentages between the perinodular epithelial compartments of CN (34 \pm 2.2 activated caspase 3-positive of $2287 \pm$ 85 , or 1 of 67 ductular epithelial cells in 10 sectors) versus DN $(3.7 \pm 0.51$ of $244.3 \pm 27.7$, or 1 of 65 cells in 10 sectors) versus $\mathrm{HCC}(0.04 \pm 0.06$ of $2.1 \pm 0.57$ cells, or 1 of 55 cells in 26 sectors) were noted $\left(P_{\mathrm{CN}}\right.$ versus $P_{\mathrm{DN}}=0.85 ; P_{\mathrm{CN}}$ versus $P_{\mathrm{HCC}}=0.844 ;$ and $P_{\mathrm{DN}}$ versus $\left.P_{\mathrm{HCC}}=0.94\right)$. Furthermore, DNA fragmentation using the TUNEL assay on formalin-fixed, paraffin-embedded sections was undertaken (Figure 3G, inset) ${ }^{19,22}$; however, DR surrounding $C N$ and DN did not demonstrate notable levels of TUNEL-positive nuclei (Figure 3G). Thus, assessment of features of both necrosis and apoptosis argue against cell death as the predominant morphologic mechanisms contributing to the documented perinodular K19 loss.

\section{Cytomorphology and Immunolabeling in the Perinodular Compartment Are Indicative of Substantial Variability in Cellular Phenotypes}

As an alternative possibility, cellular identity switch of biliarytype epithelial cells was assessed. Because relying on individual markers is insufficient for the study of cellular phenotype alterations, ${ }^{30,31}$ combined assessment of cytomorphologic features, localization, and immunophenotype was performed. ${ }^{23}$ The possibility of increased biliary-tohepatocytic transition ${ }^{32,33}$ was discounted because the perinodular and internodular zone in $\mathrm{CN}$ and $\mathrm{DN}$ demonstrated considerable numbers of weakly K19-positive epithelial cells with an elongated fibroblast-like appearance. These cells were not present within the confines of the basement membrane but were frequently associated with clusters of strongly K19-positive epithelial cells (Figure 3, C and E; see also Supplemental Figure S3, A and B, at http://ajp.amjpathol.org). In contrast, isolated epithelial-like cells within the confines of the basement membrane around $\mathrm{CN}$ and DN demonstrated strong vimentin immunoreactivity (Figure 3F; see also Supplemental Figure S3, C and D at http:// ajp.amjpathol.org). These findings suggested that perinodular K19 cell loss could be related to alterations in epithelial cellular phenotype. In addition to ascertaining staining patterns of additional markers, verification that antibodies against fibroblast-specific protein 1 (FSP-1), an S100-protein family member (also known as S100A4), label differentially when compared with S100 was performed (see Supplemental Figure S4 at http://ajp.amjpathol.org).

Absence of K19 positivity in the vicinity of $\mathrm{HCC}$ was associated with numerous FSP-1-positive cells (Figure 4A), and the few remaining K19-positive internodular ductules were in direct contact with spindleshaped FSP-1-positive cells (Figure 4A, inset). The attenuated DR around DN frequently demonstrated numerous spindle-shaped K19-positive and spindleshaped FSP-1-positive cells (Figure 4B). The complex DR around $\mathrm{CN}$ did not demonstrate FSP-1-positive cells; however, internodular ducts contained exceptionally rare FSP-1-positive or K19-negative columnar to pyramidal epithelioid cells (Figure 4C). Around DN, these FSP-1-positive epithelioid cells were more frequent (Figure 4D) and were observed as elongated 


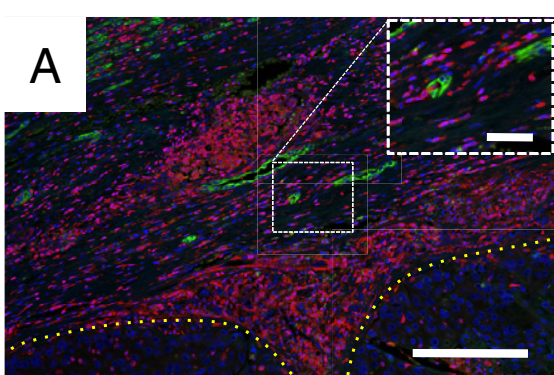

HCC: K19 FSP-1

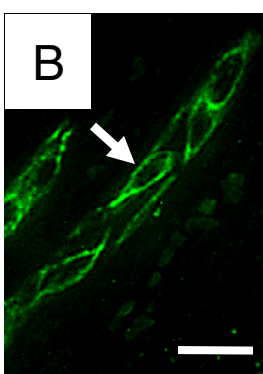

DN: K19

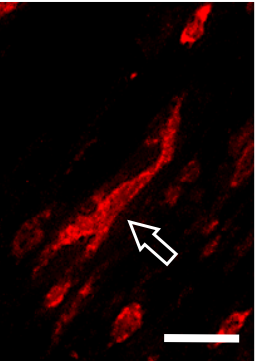

FSP-1

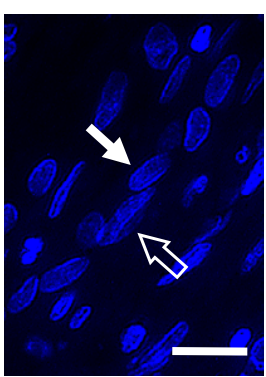

NUCLEI

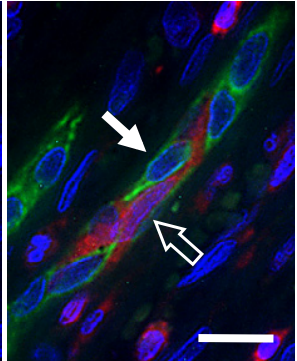

MERGE

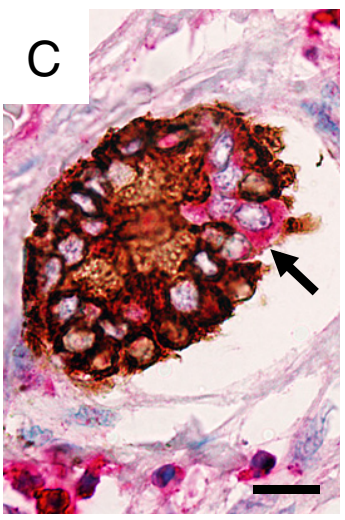

CN: K19 FSP-1

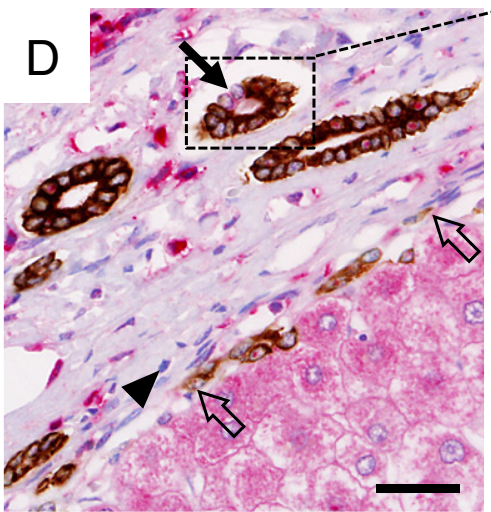

DN: K19 FSP-1

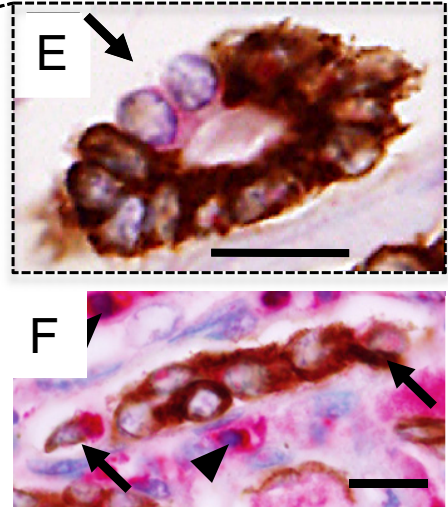

DN: K19 FSP-1

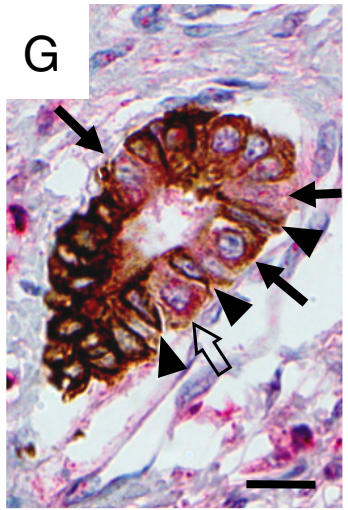

DN: K19 FSP-1

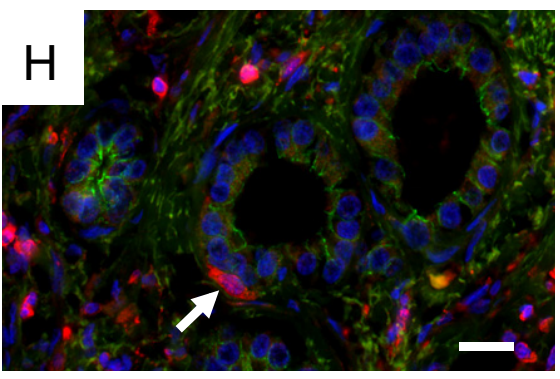

CN: ECADH FSP-1

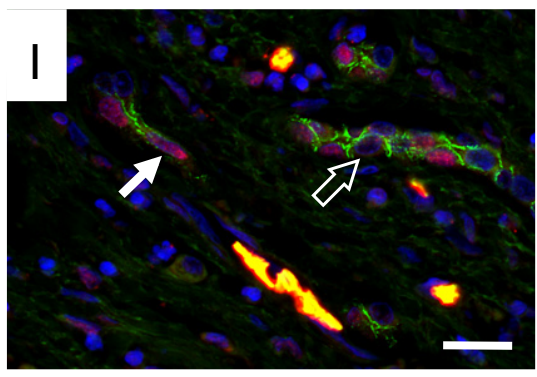

DN: ECADH SNAIL

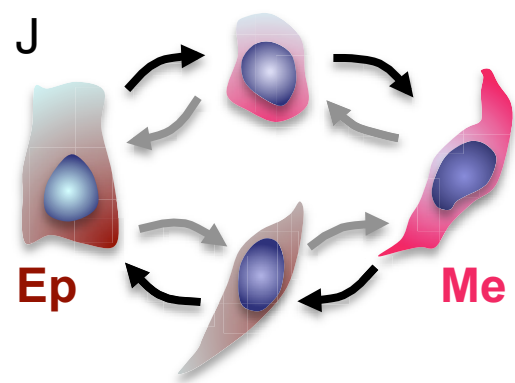

Figure 4. Epithelial phenotypes in perinodular sectors of cirrhotic nodules (CN), dysplastic nodules (DN), and hepatocellular carcinoma (HCC) using combinations of multicolor brightfield and immunofluorescence immunolabeling. A: Perinodular stroma of HCC demonstrated abundance of FSP-1 reactivity (red) and lack of K19 (green) at the hepatocellular interface (outlined in yellow). Few remaining internodular ductules demonstrated attenuated edges with lack of K19 staining and multifocal presence of FSP-1 labeling where elongated cells blend into the surrounding FSP-1-positive stroma (inset). B: Perinodular attenuated ductules around DN demonstrated numerous spindle-shaped K19-positive cells (green; arrow). Individual cells show diffuse cytoplasmic FSP-1-reactivity (red; open arrow) and nuclear features similar to nearby spindle-shaped K19-positive epithelioid cells. C: Brightfield multicolor staining of ductules around CN rarely demonstrated isolated epithelioid cells that were FSP-1-positive without K19 immunoreactivity (arrow). D: Numerous elongated or spindle-shaped fibroblast-like cells with weak K19 and FSP-1 immunoreactivity (open arrows) complemented the attenuated pattern of K19 immunoreactivity around DN (without extension between hepatocytes). Isolated or paired FSP-1-positive epithelioid cells without K19 immunoreactivity were also observed within the confines of the basement membrane (arrow in $\mathbf{D}$ and inset in $\mathbf{E}$ ). Note the dense homogeneous chromatin of stromal FSP-1-positive cellular elements (arrowhead) in comparison with the open epithelial chromatin (arrow in E), demonstrating peripheral chromatin condensation and central clearing of FSP-1-positive and K19-negative epithelioid cells. F: Attenuated ductular epithelium at the interface around DN typically demonstrated several cells with weak K19 and weak FSP-1 positivity (arrows). Compare the open epithelioid chromatin configuration with peripheral condensation and central clearing (arrows) with dense homogeneous nuclear staining of stromal and inflammatory cells (arrowhead). G: A peculiar alternating pattern of weak (arrows) and stronger (arrowheads) K19-reactivity was noted around DN. Note that some of the faint or negative epithelioid cells exhibit cytoplasmic immunoreactivity for FSP-1 (open arrowhead). H and I: Additional assessment of phenotypes included tricolor immunofluorescence for ECADH (green) in combination with FSP-1 or SNAIL, which demonstrated rare single elongated FSP-1-positive cells (red) (H), ECADH-negative cells within the confines of the basement membrane around CN (arrow in $\mathbf{H}$ ); nuclear counterstain in blue channel (see Supplemental Figure S5, A-C at http://ajp.amjpathol.org). I: SNAIL positivity in attenuated ductules around DN was observed in ECADH-positive cells (green) and ECADH-negative epithelial cells (arrow); note the presence of ECADH-positive, SNAIL-negative epithelial cells (open arrow; see Supplemental Figure S5, D-I at http://ajp.amjpatbol.org). J: Substantial variability in cellular phenotypes in the perinodular epithelial compartment of DN was assorted based on immunophenotype (Ep, epithelial marker, brown; and Me, mesenchymal marker, magenta) and cytomorphologic features (tall columnar, cuboidal, or spindle shaped). At least two distinct cellular phenotypes were observed, characterized by discrepant morphologic or immunophenotypic features suggestive of cellular identity alterations (see also Results and Discussion). Scale bars: $200 \mu \mathrm{m}(\mathbf{A}) ; 50 \mu \mathrm{m}(\mathbf{D})$ and inset in $\mathbf{A} ; 20 \mu \mathrm{m}(\mathbf{B}, \mathbf{C}$, and E-I).

cells at the hepatocellular interface zone (rim of attenuated DR; Figure 4D) or as flat cuboidal cells in internodular ducts (Figure 4D). These features of cellular identity alterations were found in both the internodular ducts (Figure 4E) and the interface zone (Figure 4F). Around DN, individual polygonal or tall to slender columnar cells demonstrated alternating strong and weak K19 staining (Figure 4G), whereby negative or faintly 
staining cells also exhibited faint cytoplasmic FSP-1 immunoreactivity (Figure 4G). Thus, K19- and FSP-1 labeling indicated substantial variability in cellular features in the perinodular compartment around DN that is morphologically and immunophenotypically compatible with cellular identity alteration. ${ }^{23}$

Confirmation of variability in cellular phenotypes was achieved by using the epithelial marker ECADH in combination with FSP-1 (Figure $4 \mathrm{H}$; see also Supplemental Figure S5, A-C, at http://ajp.amjpathol.org) or SNAIL (Figure 4I), which demonstrated spindleshaped ECADH- or SNAIL-positive cells (Figure 4l; see also Supplemental Figure S5, D-F at $h t t p: / / a j p$. amjpathol.org), as well as additional nonconventional phenotypes (see Supplemental Figure S5, G and H at http://ajp.amjpathol.org). The similarity to findings in K19 and FSP-1 labeling also included the alternating staining pattern, for example, demonstrating admixture of SNAIL-positive and SNAIL-negative cells (see Supplemental Figure S5C at http://ajp.amjpathol.org).

Of importance, all sectors contained ECADH-positive SNAIL-negative epithelial cells (Figure 4I), and these "normal" epithelial cells were observed at overall lower frequency around DN than around $\mathrm{CN}$. In contrast, cells with discrepant features (ie, epithelioid with mesenchymal immunophenotype or fibroblast-like with epithelial immunophenotype and nuclear features; Figure 4J) were more frequent around DN than around $\mathrm{CN}$. Quantification in perinodular sectors was performed; however, epithelial elements around HCC were too rare to enable meaningful random-field capture, and formal comparisons were restricted to perinodular fields in CN and DN (Table 3). Comparison of raw numbers confirmed the qualitative morphologic assessment and indicated that markers decrease in conjunction with loss of perinodular K19 structures and malignant potential of the nodule itself. Despite the overall reduced amount of FSP-1 and SNAIL around DN, marker percentages were altered. Specifically, the ECADH-positive fraction in DN was maintained, whereas the fraction of FSP-1- and SNAIL-positive epithelial cells was significantly increased (Table 3). Together these findings demonstrate increased phenotypic variability in epithelial cells around DN and support the notion that cellular phenotype alterations may contribute to perinodular K19 loss.

\section{Perinodular Epithelial Alterations Are Associated with Quantitative Differences in TGF- $\beta$ Signaling Components}

SMAD and phosphorylated SMAD (pSMAD) antibodies were tested for labeling pattern in the perinodular compartment (Table 1; see also Supplemental Figure S6 at http://ajp.amjpathol.org), and co-localization studies of K19 (Figure 5A) demonstrated increased levels of nuclear pSMAD3 around DN and in particular in those epithelial cells with weak K19 positivity (Figure 5B; see also Supplemental Figure S7, A-F, at http://ajp.amjpathol.org).
Quantification demonstrated that the significantly increased levels of pSMAD2/3 around DN compared with $\mathrm{CN}$ were associated with reduced levels of transforming growth factor beta receptor type 1 (TGF $\beta$ R1) and unaltered levels of nonactivated SMAD3 (Table 3). The alternating pattern noted in sections stained for $\mathrm{K} 19$ and FSP-1 or ECADH and SNAIL was also observed using pSMAD2/3 stains (Figure 5, D, E, G, and $\mathrm{H}$; see also Supplemental Figure S7, G-N at http://ajp.amjpathol.org) and together suggest alterations of individual cells or small clusters rather than homogeneous labeling of entire ductules (see Supplemental Figure S8 at http://ajp. amjpathol.org). When marker percentages were compared (DN:ECADH $>$ SMAD3>FSP-1>pSMAD2/3>SNAIL> TGF $\beta$ R 1 versus CN:ECADH $>$ SMAD3 $>$ TGF $\beta$ R $1>$ SNAIL $>$ pSMAD2/3>FSP-1), the partial reversal confirmed, at least by immunophenotype, a substantially different makeup of the perinodular compartment, which may reflect functional changes in signaling associated with malignant progression within the nodule.

\section{Discussion}

This study describes and further interrogates a compelling relationship of the extralesional K19 compartment that parallels intralesional malignant transformation in progressive stages of hepatocarcinogenesis in cirrhosis. In particular, K19 loss follows distinct morphologic patterns, with a complex pattern around $\mathrm{CN}$, an attenuated configuration around DN, and absence around HCC (Figure 2).

To better understand the seemingly vanishing K19 compartment, we excluded necrosis and apoptosis as morphologic mechanisms of cell loss and documented highly assorted immunophenotype along with cytomorphologic features to describe substantial variability in cellular phenotypes in the perinodular epithelial compartment. Despite existing controversies in the field of hepatocytic phenotype switch, ${ }^{30,34-37}$ alterations of ductular epithelial phenotype as it relates to progression of adjacent hepatocellular lesions have, to the best of our knowledge, not been reported. Several reports, however, have recently implicated the biliary compartment ${ }^{4,5,38,39}$ in addition to the hepatocellular compartment $\mathrm{t}^{40,41}$ as a source of stromal and mesenchymal cells, ${ }^{36}$ albeit in the nonneoplastic setting. ${ }^{42}$ For example, in EMT, expression of SNAIL leads to repression of ECADH and indirectly triggers expression of FSP-1. 4,23,35,36,43-51 Similarly, our assortment of cytomorphologic features with immunophenotype in conjunction with published criteria ${ }^{23,35}$ revealed such phenotypes (Figure 4J), ${ }^{4,23,44,51,52}$ and findings can be regarded as static morphologic indications compatible with reported stages of the various types of epithelial transition. ${ }^{35,36,53}$ Despite the compelling resemblance, the possibility of discerning dynamic processes in human tissue-based studies has important limitations. For example, differentiation of EMT from the reverse, mesenchymal-to-epithelial transformation, ${ }^{30,35}$ 


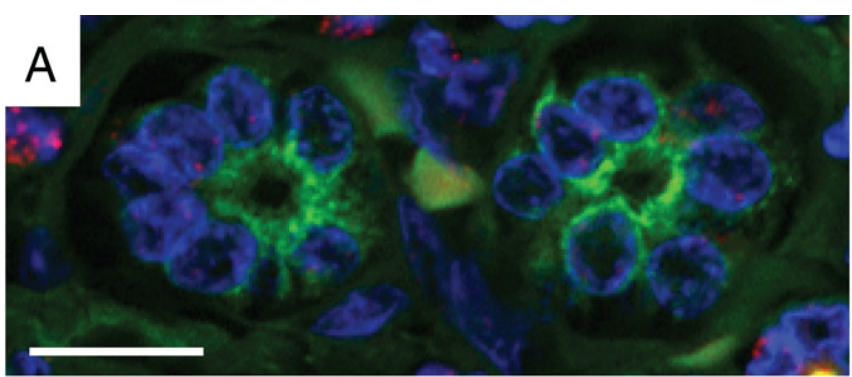

CN: K19 pSMAD3

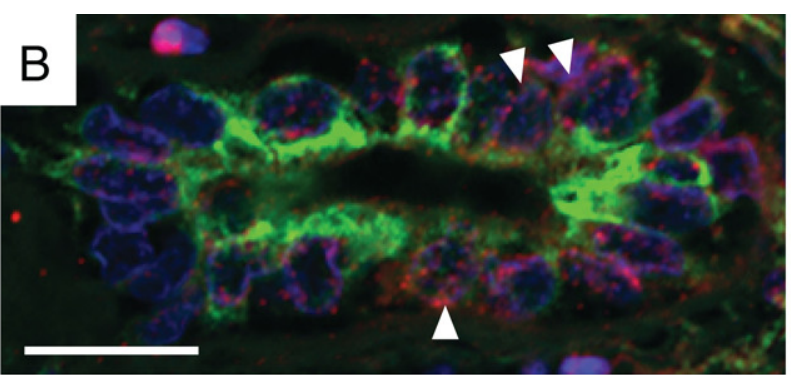

DN: K19 pSMAD3

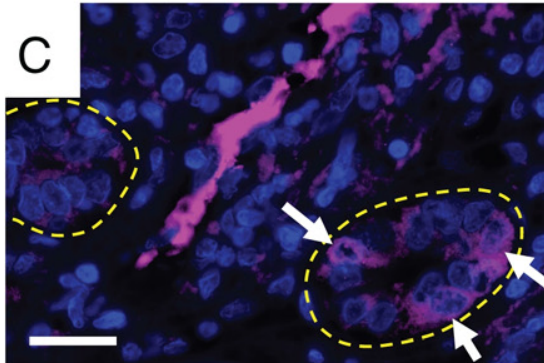

CN: TGF $\beta R 1$

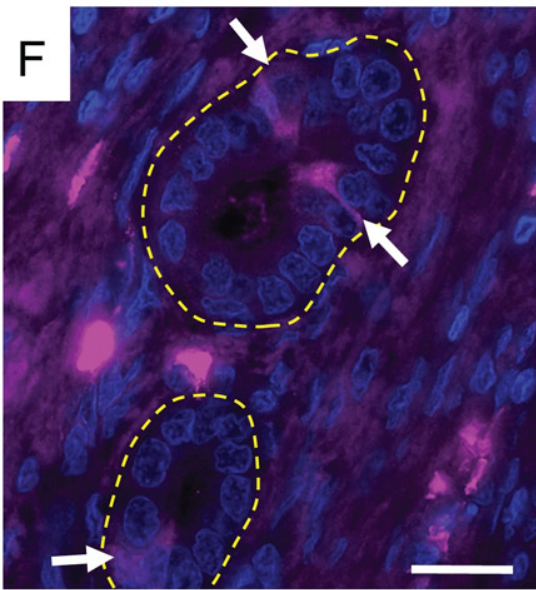

DN: TGF $\beta R 1$

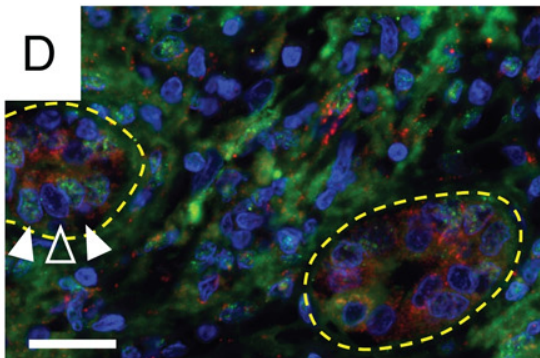

CN: SMAD3 pSMAD2/3

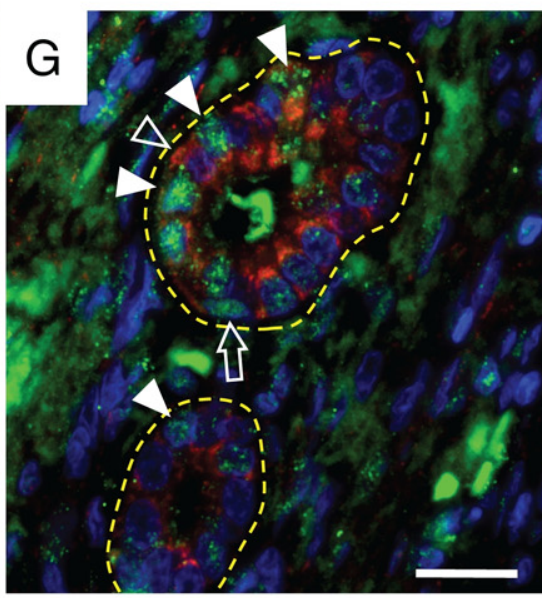

DN: SMAD3 pSMAD2/3

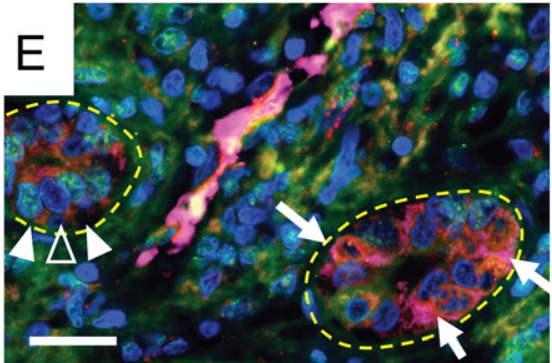

CN: TGF $\beta$ R1 SMAD3 pSMAD2/3

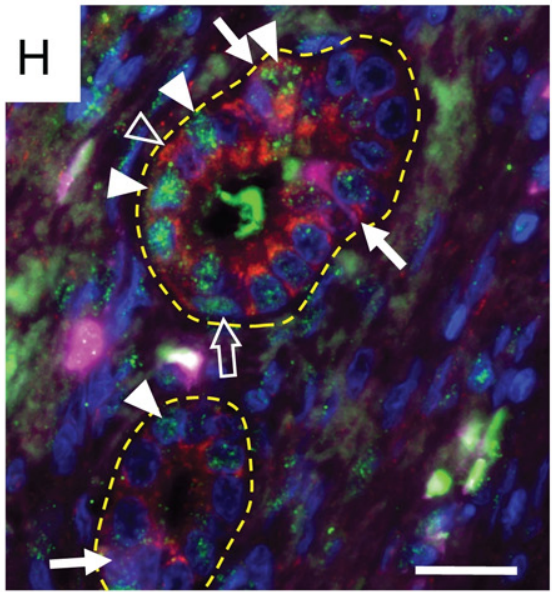

DN: TGF $\beta$ R1 SMAD3 pSMAD2/3

Figure 5. Immunolabeling of TGF- $\beta$ signaling components in the perinodular epithelial compartment of cirrhotic nodules (CN) and dysplastic nodules (DN). A: Small K19-positive (green) ductules around CN demonstrate absence or only focal spotty immunoreactivity for pSMAD3 (red). B: Ductal epithelial cells around DN demonstrated irregular K19 reactivity (green) with individual weakly staining cells (compare staining pattern with brightfield appearance in Figure 4G); some of these demonstrated nuclear pSMAD3 reactivity (red; arrowheads). C: Small ductules around CN (outlined in C-E) demonstrated TGF $\beta$ R1 expression (magenta) in isolated cone- or pyramid-shaped cells (arrows). Note the lack of nuclear TGF $\beta R 1$ staining (Hoechst, blue). D: Most ductal epithelial cells demonstrated cytoplasmic SMAD3 positivity (red), whereas only a small fraction of nuclei (blue) were pSMAD2/3-positive, resulting in the merged color turquoise (filled arrowheads). Note the alternating organization with interspersed pSMAD-negative nuclei (open arrowhead). E: Quadruple merge illustrated presence of TGF $\beta$ R1 expression in cells with cytoplasmic SMAD3 (arrows), indicative of at least two components of the TGF- $\beta$ signaling pathway in cells without immunoreactivity for activated components (pSMAD2/3-negative). F: Small ductules around DN (outlined in F-H) demonstrated TGF $\beta$ R1-expressing epithelial cells (arrows). G: Cytoplasmic SMAD3 staining (red) was similar to that observed in ductules around CN (D); however, the number and staining intensity of pSMAD2/3 (green) in ductular nuclei (blue) was increased (merged color turquoise; filled arrowheads). Note individual pSMAD2/3-positive flat circumferentially oriented nuclei within the confines of the basement membrane (open arrow) and individual pSMAD2/3-negative interspersed nuclei (open arrowhead). H: Quadruple merge illustrates presence of TGF $\beta$ R1 expression in cells with cytoplasmic SMAD3 (arrows), as well as focal nuclear pSMAD2/3 staining (arrowheads), and interspersed pSMAD2/3-negative nuclei (open arrowhead). Circumferentially oriented nucleus (open arrow) (G; see also Supplemental Figure S7 at http://ajp.amjpathol.org). Scale bars $=20 \mu \mathrm{m}$.

or maintenance of a plastic phenotype (dynamic reversibility $)^{51,54,55}$ is not possible, and we abstain from attributing directionality, time scale, reversibility, and bidirectionality or whether alterations represent the pivotal underlying structural mechanism of perinodular K19 loss. Furthermore, definitive proof that perinodular K19-positive cells are able to transdifferentiate into mesenchymal elements would require in vivo lineage tracing with cholangiocyte-specific marker genes, ${ }^{56}$ and even then, the lack of reliable animal models for HCC in the setting of cirrhosis ${ }^{57}$ will make further experimental exploration of possible mechanisms challenging.

To further narrow a connection of perinodular epithelial cell loss and hepatocellular neoplasia at the tissue level, we interrogated putative upstream signaling pathways, and although a variety of neuroendocrine factors influ- 
ence biliary epithelial function, ${ }^{58-60}$ we focused on TGF- $\beta$ because of its major profibrogenic role, ${ }^{61}$ established implications in human biliary EMT, 4,55,62 and signaling upstream of SNAIL via recruitment of SMAD molecules ${ }^{4,55,62-66}$ and because assessment of pSMAD2/3 via immunolabeling in formalin-fixed, paraffin-embedded samples has been reported. $4,55,59,62,66$ Our findings of increased levels of nuclear PSMAD were indicative of increased levels of activated TGF- $\beta$ signaling around DN; however, in combination with reduced TGF $\beta$ R1 levels, recruitment of alternative upstream activators in dysplasia remains possible. ${ }^{55}$ Methodologic limitations of assessing signaling status or nucleotide incorporation in formalin-fixed, paraffin-embedded samples apply. 34,67 Nonetheless, the reproducibility using different antibodies in a large number of nodules that includes alternating PSMAD staining patterns also observed using K19 or FSP-1 and ECADH or SNAIL labeling suggest morphologic and immunophenotypic alterations in the tight locoregional control of the functional heterogeneity in biliary epithelial cells ${ }^{68}$ in progressive stages of hepatocarcinogenesis.

In conjunction, the observed structural alterations are associated with discrepancies regarding cellular identity and alterations in TGF- $\beta$ signaling, and we propose paracrine signaling across the lesional interface as a possible underlying pathophysiologic link. This hypothesis of paracrine signaling does not exclude additional contributing mechanisms such as non-TGF- $\beta$-mediated triggers (eg, tyrosine-kinase-mediated signaling or hedgehog signaling ${ }^{39,41,50,56}$ ); stromal and mesenchymal factors such as immunoregulatory, inflammatory, or stromal cells 4,48,69,70; extrahepatic so-called circulating stem cells $^{71,72}$; autophagy-associated (caspase-independent) cell death ${ }^{18}$; or changes in anoikis (apoptosis induced by detachment from anchorage). ${ }^{73}$ Inasmuch as similar signaling has been demonstrated in the setting of biliary fibrosis, ${ }^{39}$ our results implicate the K19 compartment as a morphologically distinct and significant stromal (epithelial) factor in HCC pathogenesis in cirrhosis. It remains to be determined whether perinodular phenomena also apply to the noncirrhotic liver; however, we examined perinodular sectors in a variety of underlying diseases, and DN occur predominantly, if not only, in the setting of cirrhosis. ${ }^{6,7,9,11,74-78}$ The observed progressive alterations in the ductular compartment of premalignant and malignant hepatocellular lesions also indicate a substantial change in the otherwise prototypic ductular response to chronic injury (ie, cirrhosis). ${ }^{1-3,79}$ In addition to exhaustion of the K19-based stem cell niche, ${ }^{32,33,56,79,80}$ our findings emphasize alterations of an intricate relationship between intralesional and extralesional compartments as hepatocarcinogenesis progresses. Notwithstanding the known relation of intranodular mesenchymal elements of HCC (eg, reticulin pattern, unpaired arteries, sinusoidal capillarization, and vascular and extranodular stromal invasion $^{9,10,76,77}$ ), as well as imaging applications that use altered vascular biology in HCC for detection via dynamic methods, ${ }^{81}$ changes in the nonhepatocellular epithelial compartment remain largely unexplored, ${ }^{7,8,16,45}$ and our findings provide a morphologic starting point to examine whether loss of perinodular DR is a bystanding or contributing factor in progressive stages of hepatocarcinogenesis.

In terms of application in routine diagnostic pathology, the present study demonstrates that perinodular K19 patterns can function as a highly reliable extralesional surrogate for intralesional disease, with sensitivity and specificity values well above $83 \%$, even when atypical hepatocellular lesions were included (Table 2). However, it remains to be determined whether perinodular $\mathrm{K} 19$ assessment can overcome the recognized limitations associated with needle core biopsy sampling. ${ }^{78,82,83}$ Based on our preliminary case-based evidence, ${ }^{9}$ assessment of the perinodular K19 pattern in biopsy specimens is possible; however, it is questionable how regional variability and limited sampling will alter the overall good diagnostic performance (Table 2). Caution must be used in interpretation of immunohistochemical findings in the context of cancer diagnostics. The perinodular K19 pattern in the setting of cirrhosis and encapsulated HCC will likely demonstrate absence adjacent to HCC; however, this should not diminish careful examination of the lesion using traditional means. Nonetheless, the widespread availability of $\mathrm{K} 19$ staining and straightforward assessment (Figure 2) adds a pattern-based extralesional feature to existing strategies, ${ }^{74,75,84}$ which should encourage external validation as a diagnostic tool. ${ }^{86}$

\section{Acknowledgments}

We thank Julie Gutierrez, Elease Barnes, Shari Jackson, and Mary Madden for administrative assistance; Autumn Watson, Vernetta Layton, Kevin Selle, Don Leahart, Kevin Keith, and Rodney Brown for histotechnical assistance; Jianping Li, Xiaopei Zhu, and Prosperidad Amargo for technical assistance; Joan Rossi and Dr. Jason Mills for microscope use; Walter Clermont, Stacey Yates, Emily Brophy, and Mike Isaacs for slide scanning and information technology support; Dr. James S. Lewis, Jr, and the research histology laboratory; Drs. John D. Pfeifer and Peter Humphrey (Washington University/Barnes-Jewish Hospital) and Drs. Gregory Y. Lauwers and John Gilbertson (Massachusetts General Hospital/Harvard Medical School) for support and thoughtful discussions.

\section{References}

1. Roskams T, Desmet V: Ductular reaction and its diagnostic significance. Semin Diagn Pathol 1998, 15:259-269

2. Desmet V, Roskams T, Van Eyken P: Ductular reaction in the liver Pathol Res Pract 1995, 191:513-524

3. Popper H, Kent G, Stein R: Ductular cell reaction in the liver in hepatic injury. J Mt Sinai Hosp NY 1957, 24:551-556

4. Rygiel KA, Robertson H, Marshall HL, Pekalski M, Zhao L, Booth TA, Jones DE, Burt AD, Kirby JA: Epithelial-mesenchymal transition contributes to portal tract fibrogenesis during human chronic liver disease. Lab Invest 2008, 88:112-123

5. Kirby JA, Robertson H, Marshall HL, Rygiel KA, Hudson M, Jones DE Burt AD: Epithelial to mesenchymal transition in primary sclerosing cholangitis. Liver Int 2008, 28:1176-1177

6. Kojiro M: Pathological diagnosis at early stage: reaching international consensus. Oncology 78(Suppl 1):31-35 
7. Park YN, Kojiro M, Di Tommaso L, Dhillon AP, Kondo F, Nakano M, Sakamoto M, Theise ND, Roncalli M: Ductular reaction is helpful in defining early stromal invasion, small hepatocellular carcinomas, and dysplastic nodules. Cancer 2007, 109:915-923

8. van Zijl F, Mair M, Csiszar A, Schneller D, Zulehner G, Huber H, Eferl $\mathrm{R}$, Beug $\mathrm{H}$, Dolznig $\mathrm{H}$, Mikulits W: Hepatic tumor-stroma crosstalk guides epithelial to mesenchymal transition at the tumor edge. Oncogene 2009, 28:4022-4033

9. Lennerz JK, Crippin JS, Brunt EM: Diagnostic considerations of nodules in the cirrhotic liver: a case-based perspective. Pathol Case Rev 2009, 14:3-12

10. International Working Party: Terminology of nodular hepatocellular lesions. Hepatology 1995, 22:983-993

11. Hytiroglou P, Park YN, Krinsky G, Theise ND: Hepatic precancerous lesions and small hepatocellular carcinoma. Gastroenterol Clin North Am 2007, 36:867-887, vii

12. Lefkowitch $\mathrm{JH}$ : Hepatobiliary pathology. Curr Opin Gastroenterol 2008, 24:269-277

13. Moll R, Franke WW, Schiller DL, Geiger B, Krepler R: The catalog of human cytokeratins: patterns of expression in normal epithelia, tumors and cultured cells. Cell 1982, 31:11-24

14. Tan J, Hytiroglou P, Wieczorek R, Park YN, Thung SN, Arias B, Theise ND: Immunohistochemical evidence for hepatic progenitor cells in liver diseases. Liver 2002, 22:365-373

15. Van Eyken P, Desmet VJ: Cytokeratins and the liver. Liver 1993 13:113-122

16. Terada T, Hoso M, Nakanuma Y: Distribution of cytokeratin 19positive biliary cells in cirrhotic nodules, hepatic borderline nodules (atypical adenomatous hyperplasia), and small hepatocellular carcinomas. Mod Pathol 1995, 8:371-379

17. Malhi H, Gores GJ, Lemasters JJ: Apoptosis and necrosis in the liver: a tale of two deaths? Hepatology 2006, 43:S31-S44

18. Hotchkiss RS, Strasser A, McDunn JE, Swanson PE: Cell death. N Engl J Med 2009, 361:1570-1583

19. Zhivotovsky B, Orrenius S: Assessment of apoptosis and necrosis by DNA fragmentation and Morphological Criteria. Curr Protoc Cell Biol 2001, Chapter 18: Unit 18.3

20. Bowen ID: Techniques for demonstrating cell death. Cell Death in Biology and Pathology. Edited by Bowen ID, Lockshin RA. LondonNew York, Chapman \& Hall, 1981, pp. 379-444

21. Kerr JF, Wyllie AH, Currie AR: Apoptosis: a basic biological phenomenon with wide-ranging implications in tissue kinetics. $\mathrm{Br} \mathrm{J}$ Cancer 1972, 26:239-257

22. Gavrieli Y, Sherman Y, Ben-Sasson SA: Identification of programmed cell death in situ via specific labeling of nuclear DNA fragmentation. J Cell Biol 1992, 119:493-501

23. Zeisberg M, Neilson EG: Biomarkers for epithelial-mesenchymal transitions. J Clin Invest 2009, 119:1429-1437

24. Lennerz JK, Kim SH, Oates EL, Huh WJ, Doherty JM, Tian X, Bredemeyer AJ, Goldenring JR, Lauwers GY, Shin YK, Mills JC: The transcription factor MIST1 is a novel human gastric chief cell marker whose expression is lost in metaplasia, dysplasia, and carcinoma. Am J Pathol 2010, 177:1514-1533

25. Lennerz JK, Ruhle V, Ceppa EP, Neuhuber WL, Bunnett NW, Grady EF, Messlinger K: Calcitonin receptor-like receptor (CLR), receptor activity-modifying protein 1 (RAMP1), and calcitonin gene-related peptide (CGRP) immunoreactivity in the rat trigeminovascular system: differences between peripheral and central CGRP receptor distribution. J Comp Neurol 2008, 507:1277-1299

26. Berglund L, Bjorling E, Oksvold P, Fagerberg L, Asplund A, Szigyarto CA, Persson A, Ottosson J, Wernerus $H$, Nilsson P, Lundberg E, Sivertsson A, Navani S, Wester K, Kampf C, Hober S, Ponten F, Uhlen M: A genecentric human protein atlas for expression profiles based on antibodies. Mol Cell Proteomics 2008, 7:2019-2027

27. Silcocks PB: Measuring repeatability and validity of histological diagnosis: a brief review with some practical examples. J Clin Pathol 1983, 36:1269-1275

28. Pupure J, Isajevs S, Skapare E, Rumaks J, Svirskis S, Svirina D, Kalvinsh I, Klusa V: Neuroprotective properties of mildronate, a mitochondria-targeted small molecule. Neurosci Lett 2010, 470:100-105

29. Aguzzi MS, Fortugno P, Giampietri C, Ragone G, Capogrossi MC Facchiano A: Intracellular targets of RGDS peptide in melanoma cells. Mol Cancer 2010, 9:84
30. Tarin D, Thompson EW, Newgreen DF: The fallacy of epithelial mesenchymal transition in neoplasia. Cancer Res 2005, 65:5996-6000; discussion 6000-5991

31. Zhang DW, Bian $\mathrm{H}$ : No contribution to liver fibrosis, but possible carcinogenesis? Hepatology 51:1468-1469; author reply 1469

32. Kuwahara R, Kofman AV, Landis CS, Swenson ES, Barendswaard E, Theise ND: The hepatic stem cell niche: identification by label-retaining cell assay. Hepatology 2008, 47:1994-2002

33. Roskams TA, Theise ND, Balabaud C, Bhagat G, Bhathal PS, BioulacSage P, Brunt EM, Crawford JM, Crosby HA, Desmet V, Finegold MJ, Geller SA, Gouw AS, Hytiroglou P, Knisely AS, Kojiro M, Lefkowitch JH, Nakanuma Y, Olynyk JK, Park YN, Portmann B, Saxena R, Scheuer PJ, Strain AJ, Thung SN, Wanless IR, West AB: Nomenclature of the finer branches of the biliary tree: canals, ductules, and ductular reactions in human livers. Hepatology 2004, 39:1739-1745

34. Taura K, Miura K, Iwaisako K, Osterreicher CH, Kodama Y, PenzOsterreicher M, Brenner DA: Hepatocytes do not undergo epithelialmesenchymal transition in liver fibrosis in mice. Hepatology 2010 , 51:1027-1036

35. Giannelli G: The epithelial-mesenchymal transition: fact or fiction in cancer? Hepatology 2009, 50:1344-1346

36. Wells RG: The epithelial-to-mesenchymal transition in liver fibrosis: here today, gone tomorrow? Hepatology 2010, 51:737-740

37. Scholten D, Scholten A, Brenner DA, Kisseleva T: Epithelial-to-mesenchymal transition (EMT) in cholangiocytes does not contribute to liver fibrosis. Hepatology 2009, 50(Suppl):818A

38. Robertson H, Kirby JA, Yip WW, Jones DE, Burt AD: Biliary epithelialmesenchymal transition in posttransplantation recurrence of primary biliary cirrhosis. Hepatology 2007, 45:977-981

39. Omenetti A, Porrello A, Jung Y, Yang L, Popov Y, Choi SS, Witek RP Alpini G, Venter J, Vandongen HM, Syn WK, Baroni GS, Benedetti A, Schuppan D, Diehl AM: Hedgehog signaling regulates epithelialmesenchymal transition during biliary fibrosis in rodents and humans. J Clin Invest 2008, 118:3331-3342

40. Zeisberg M, Yang C, Martino M, Duncan MB, Rieder F, Tanjore $H$, Kalluri R: Fibroblasts derive from hepatocytes in liver fibrosis via epithelial to mesenchymal transition. J Biol Chem 2007, 282:2333723347

41. Choi SS, Omenetti A, Witek RP, Moylan CA, Syn WK, Jung Y, Yang L, Sudan DL, Sicklick JK, Michelotti GA, Rojkind M, Diehl AM: Hedgehog pathway activation and epithelial-to-mesenchymal transitions during myofibroblastic transformation of rat hepatic cells in culture and cirrhosis. Am J Physiol Gastrointest Liver Physiol 2009, 297: G1093-G1106

42. Fabris L, Strazzabosco M: Epithelial-mesenchymal interactions in biliary diseases. Semin Liver Dis 2011, 31:11-32

43. Strutz F, Okada H, Lo CW, Danoff T, Carone RL, Tomaszewski JE, Neilson EG: Identification and characterization of a fibroblast marker: fSP1. J Cell Biol 1995, 130:393-405

44. Mazzucchelli L: Protein S100A4: too long overlooked by pathologists?. Am J Pathol 2002, 160:7-13

45. Yang MH, Chen CL, Chau GY, Chiou SH, Su CW, Chou TY, Peng WL, WU JC: Comprehensive analysis of the independent effect of Twist and Snail in promoting metastasis of hepatocellular carcinoma. Hepatology 2009, 50:1464-1474

46. Nieto MA: The snail superfamily of zinc-finger transcription factors. Nat Rev Mol Cell Biol 2002, 3:155-166

47. Le Hir M, Hegyi I, Cueni-Loffing D, Loffing J, Kaissling B: Characterization of renal interstitial fibroblast-specific protein 1/S100A4positive cells in healthy and inflamed rodent kidneys. Histochem Cell Biol 2005, 123:335-346

48. Robertson H, Ali S, McDonnell BJ, Burt AD, Kirby JA: Chronic renal allograft dysfunction: the role of $\mathrm{T}$ cell-mediated tubular epithelial to mesenchymal cell transition. J Am Soc Nephrol 2004, 15:390-397

49. Cano A, Perez-Moreno MA, Rodrigo I, Locascio A, Blanco MJ, del Barrio MG, Portillo F, Nieto MA: The transcription factor snail controls epithelial-mesenchymal transitions by repressing E-cadherin expression. Nat Cell Biol 2000, 2:76-83

50. Huber MA, Kraut N, Beug $\mathrm{H}$ : Molecular requirements for epithelialmesenchymal transition during tumor progression. Curr Opin Cell Biol 2005, 17:548-558

51. Kalluri R, Neilson EG: Epithelial-mesenchymal transition and its implications for fibrosis. J Clin Invest 2003, 112:1776-1784 
52. Okada H, Danoff TM, Kalluri R, Neilson EG: Early role of Fsp1 in epithelial-mesenchymal transformation. Am J Physiol 1997, 273: F563-F574

53. Wasilenko S, Mason AL: New insights from recurrent primary biliary cirrhosis in liver transplantation: the paradox of becoming a fibroblast? Hepatology 2007, 45:837-840

54. Iwano M, Plieth D, Danoff TM, Xue C, Okada H, Neilson EG: Evidence that fibroblasts derive from epithelium during tissue fibrosis. J Clin Invest 2002, 110:341-350

55. Tyler JR, Robertson H, Booth TA, Burt AD, Kirby JA: Chronic allograft nephropathy: intraepithelial signals generated by transforming growth factor-beta and bone morphogenetic protein-7. Am J Transplant 2006, 6:1367-1376

56. Greenbaum LE: Hedgehog signaling in biliary fibrosis. J Clin Invest 2008, 118:3263-3265

57. Fausto N, Campbell JS: Mouse models of hepatocellular carcinoma Semin Liver Dis 2010, 30:87-98

58. Glaser SS, Gaudio E, Miller T, Alvaro D, Alpini G: Cholangiocyte proliferation and liver fibrosis. Exp Rev Mol Med 2009, 11:e7

59. Kiss A, Schnur J, Szabo Z, Nagy P: Immunohistochemical analysis of atypical ductular reaction in the human liver, with special emphasis on the presence of growth factors and their receptors. Liver 2001 , 21:237-246

60. Llovet JM, Bruix J: Molecular targeted therapies in hepatocellular carcinoma. Hepatology 2008, 48:1312-1327

61. Gressner AM, Weiskirchen R, Breitkopf K, Dooley S: Roles of TGFbeta in hepatic fibrosis. Front Biosci 2002, 7:d793-d807

62. Tan CE, Chan VS, Yong RY, Vijayan V, Tan WL, Fook Chong SM, Ho $\mathrm{JM}$, Cheng $\mathrm{HH}$ : Distortion in TGF beta 1 peptide immunolocalization in biliary atresia: comparison with the normal pattern in the developing human intrahepatic bile duct system. Pathol Int 1995, 45:815-824

63. ten Dijke P, Hill CS: New insights into TGF-beta-Smad signalling Trends Biochem Sci 2004, 29:265-273

64. Dooley S, Hamzavi J, Ciuclan L, Godoy P, Ilkavets I, Ehnert S, Ueberham E, Gebhardt R, Kanzler S, Geier A, Breitkopf K, Weng H, Mertens PR: Hepatocyte-specific Smad7 expression attenuates TGFbeta-mediated fibrogenesis and protects against liver damage. Gastroenterology 2008, 135:642-659

65. Stopa M, Anhuf D, Terstegen L, Gatsios P, Gressner AM, Dooley S Participation of Smad2, Smad3, and Smad4 in transforming growth factor beta (TGF-beta)-induced activation of Smad7 THE TGF-beta response element of the promoter requires functional Smad binding element and E-box sequences for transcriptional regulation. J Bio Chem 2000, 275:29308-29317

66. Zeisberg M, Hanai J, Sugimoto H, Mammoto T, Charytan D, Strutz F Kalluri R: BMP-7 counteracts TGF-beta1-induced epithelial-to-mesenchymal transition and reverses chronic renal injury. Nat Med 2003 , 9:964-968

67. Grasl-Kraupp B, Ruttkay-Nedecky B, Koudelka H, Bukowska K, Bursch W, Schulte-Hermann R: In situ detection of fragmented DNA (TUNEL assay) fails to discriminate among apoptosis, necrosis, and autolytic cell death: a cautionary note. Hepatology 1995, 21:14651468

68. Kanno N, LeSage G, Glaser S, Alvaro D, Alpini G: Functional heterogeneity of the intrahepatic biliary epithelium. Hepatology 2000, 31 : 555-561

69. Cepek KL, Shaw SK, Parker CM, Russell GJ, Morrow JS, Rimm DL, Brenner MB: Adhesion between epithelial cells and T Iymphocytes mediated by E-cadherin and the alpha E beta 7 integrin. Nature 1994 372:190-193

70. Fu S, Zhang N, Yopp AC, Chen D, Mao M, Zhang H, Ding Y, Bromberg JS: TGF-beta induces Foxp3 + T-regulatory cells from CD4+CD25- precursors. Am J Transplant 2004, 4:1614-1627

71. Kisseleva T, Uchinami H, Feirt N, Quintana-Bustamante O, Segovia JC, Schwabe RF, Brenner DA: Bone marrow-derived fibrocytes participate in pathogenesis of liver fibrosis. J Hepatol 2006, 45:429-438

72. Forbes SJ, Russo FP, Rey V, Burra P, Rugge M, Wright NA, Alison MR: A significant proportion of myofibroblasts are of bone marrow origin in human liver fibrosis. Gastroenterology 2004, 126:955-963

73. Frisch SM, Screaton RA: Anoikis mechanisms. Curr Opin Cell Biol 2001, 13:555-562

74. Di Tommaso L, Destro A, Seok JY, Balladore E, Terracciano L, Sangiovanni A, lavarone M, Colombo M, Jang JJ, Yu E, Jin SY, Morenghi E, Park YN, Roncalli M: The application of markers (HSP70 GPC3 and
GS) in liver biopsies is useful for detection of hepatocellular carcinoma. J Hepatol 2009, 50:746-754

75. Di Tommaso L, Franchi G, Park YN, Fiamengo B, Destro A, Morenghi E, Montorsi M, Torzilli G, Tommasini M, Terracciano L, Tornillo L, Vecchione R, Roncalli M: Diagnostic value of HSP70, glypican 3, and glutamine synthetase in hepatocellular nodules in cirrhosis. Hepatology 2007, 45:725-734

76. Park YN, Yang CP, Fernandez GJ, Cubukcu O, Thung SN, Theise ND: Neoangiogenesis and sinusoidal "capillarization" in dysplastic nodules of the liver. Am J Surg Pathol 1998, 22:656-662

77. Roncalli M, Borzio M, Di Tommaso L: Hepatocellular dysplastic nodules. Hepatol Res 2007, 37(Suppl 2):S125-S134

78. Wanless IR: Liver biopsy in the diagnosis of hepatocellular carcinoma. Clin Liver Dis 2005, 9:281-285, vi

79. Falkowski $O$, An $H J$, lanus IA, Chiriboga $L$, Yee $H$, West $A B$, Theise ND: Regeneration of hepatocyte "buds" in cirrhosis from intrabiliary stem cells. J Hepatol 2003, 39:357-364

80. Yoon SM, Gerasimidou D, Kuwahara R, Hytiroglou P, Yoo JE, Park YN, Theise ND: Epithelial cell adhesion molecule (EpCAM) marks hepatocytes newly derived from stem/progenitor cells in humans. Hepatology 2011, 53:964-973

81. Bruix J, Sherman M: Management of hepatocellular carcinoma Hepatology 2005, 42:1208-1236

82. Kalinski T, Roessner A: Hepatocellular carcinoma: pathology and liver biopsy. Dig Dis 2009, 27:102-108

83. Roncalli M: Hepatocellular nodules in cirrhosis: focus on diagnostic criteria on liver biopsy: a Western experience. Liver Transpl 2004 10:S9-S15

84. Jain R, Fischer S, Serra S, Chetty R: The use of cytokeratin 19 (CK19) immunohistochemistry in lesions of the pancreas, gastrointestina tract, and liver. Appl Immunohistochem Mol Morphol 2010, 18:9-15

85. Choi YJ, Pinto MM, Hao L, Riba AK: Interobserver variability and aberrant E-cadherin immunostaining of lobular neoplasia and infiltrating lobular carcinoma. Mod Pathol 2008, 21:1224-1237

86. Bergstrom R, Savary K, Moren A, Guibert S, Heldin CH, Ohlsson R, Moustakas A: Transforming growth factor beta promotes complexes between Smad proteins and the CCCTC-binding factor on the $\mathrm{H} 19$ imprinting control region chromatin. J Biol Chem 2010, 285:1972719737

87. Baghy K, Dezso K, Laszlo V, Fullar A, Peterfia B, Paku S, Nagy P, Schaff Z, Iozzo RV, Kovalszky I: Ablation of the decorin gene enhances experimental hepatic fibrosis and impairs hepatic healing in mice. Lab Invest 2011, 91:439-451

88. Kahn HJ, Marks A, Thom H, Baumal R: Role of antibody to $\mathrm{S} 100$ protein in diagnostic pathology. Am J Clin Pathol 1983, 79:341-347

89. Vincent T, Neve EP, Johnson JR, Kukalev A, Rojo F, Albanell J, Pietras K, Virtanen I, Philipson L, Leopold PL, Crystal RG, de Herreros AG, Moustakas A, Pettersson RF, Fuxe J: A SNAIL1-SMAD3/4 transcriptional repressor complex promotes TGF-beta mediated epithelialmesenchymal transition. Nat Cell Biol 2009, 11:943-950

90. Li Q, Pangas SA, Jorgez CJ, Graff JM, Weinstein M, Matzuk MM: Redundant roles of SMAD2 and SMAD3 in ovarian granulosa cells in vivo. Mol Cell Biol 2008, 28:7001-7011

91. Bardeesy N, Cheng KH, Berger JH, Chu GC, Pahler J, Olson P, Hezel AF, Horner J, Lauwers GY, Hanahan D, DePinho RA: Smad4 is dispensable for normal pancreas development yet critical in progression and tumor biology of pancreas cancer. Genes Dev 2006, 20 : 3130-3146

92. Hornick JL, Lauwers GY, Odze RD: Immunohistochemistry can help distinguish metastatic pancreatic adenocarcinomas from bile duct adenomas and hamartomas of the liver. Am J Surg Pathol 2005, 29:381-389

93. Van Themsche C, Chaudhry P, Leblanc V, Parent S, Asselin E: XIAP gene expression and function is regulated by autocrine and paracrine TGF-beta signaling. Mol Cancer 2010, 9:216

94. Louafi F, Martinez-Nunez RT, Sanchez-Elsner T: MicroRNA-155 targets SMAD2 and modulates the response of macrophages to transforming growth factor-\{beta\}. J Biol Chem 2010, 285:41328-41336

95. Kondo M, Cubillo E, Tobiume K, Shirakihara T, Fukuda N, Suzuki H, Shimizu K, Takehara K, Cano A, Saitoh M, Miyazono K: A role for Id in the regulation of TGF-beta-induced epithelial-mesenchymal transdifferentiation. Cell Death Differ 2004, 11:1092-1101 
96. Rachakonda G, Sekhar KR, Jowhar D, Samson PC, Wikswo JP, Beauchamp RD, Datta PK, Freeman ML: Increased cell migration and plasticity in Nrf2-deficient cancer cell lines. Oncogene 29 3703-3714

97. Huang W, Zhang Y, Varambally S, Chinnaiyan AM, Banerjee M, Merajver SD, Kleer CG: Inhibition of CCN6 (Wnt-1-induced signaling protein 3) down-regulates E-cadherin in the breast epithelium through induction of snail and ZEB1. Am J Pathol 2008, 172:893904
98. Tzur G, Israel A, Levy A, Benjamin H, Meiri E, Shufaro Y, Meir K, Khvalevsky E, Spector Y, Rojansky N, Bentwich Z, Reubinoff BE, Galun E: Comprehensive gene and microRNA expression profiling reveals a role for microRNA in human liver development. PLoS One 2009, 4:e7511

99. Azumi N, Battifora $\mathrm{H}$ : The distribution of vimentin and keratin in epithelial and nonepithelial neoplasms: a comprehensive immunohistochemical study on formalin- and alcohol-fixed tumors. Am J Clin Pathol 1987, 88:286-296 